\title{
Pathogenesis of infectious diarrhea
}

\author{
John Stephen BSc PhD
}

J Stephen. Pathogenesis of infectious diarrhea. Can J Gastroenterol 2001;15(10):669-683. A brief overview of some of the main features involved in normal physiological bidirectional absorption and secretion of fluid in the gut is given, including the nature and cellular location of key enzymes, ion pumps, symports, antiports and diffusion channels; the microanatomy of intestinal villous vasculature and the dynamics of villus blood flow, which together generate hypertonic zones in villus tip regions; and the production, differentiation, escalator movement (from crypt to villus tip) and subsequent shedding of intestinal epithelial cells. (Neural and hormonal mechanisms that regulate normal mucosal ion transport are not discussed.) The manner in which Vibrio cholerae, several pathotypes of Escherichia coli, several Salmonella serotypes, rotavirus, Campylobacter species, Shigella dysenteriae, Yersinia species and Clostridium difficile perturb these mechanisms and cause diarrhea, is discussed. Throughout the article, the main emphasis is on experimental studies designed to elucidate biological mechanisms and (where relevant) the microbial determinants responsible for diarrheal disease. Allusions are also made to the involvement of host responses such as the inflammatory response, the production and release of potent cytokines and accelerated homeostatic responses (such as increased rates of crypt cell division seen in some infections), and the role that they play in pathophysiological fluid secretion.

Key Words: Diarrhea; Escherichia coli; Bibrio cholerae; Clostridium difficile; Shigella dysenteriae

\section{Pathogenèse de la diarrhée infectieuse}

RÉSUMÉ : Le présent article donne un bref aperçu des principales caractéristiques de la physiologie normale de l'absorption et de la sécrétion bidirectionnelles des liquides dans l'intestin; il sera question, entre autres, de la nature et du siège cellulaire des principales enzymes; des pompes à ions, des symports, des antiports et des canaux de diffusion; de la micro-anatomie du système vasculaire des villosités de l'intestin et de la dynamique du débit sanguin dans ces villosités qui, ensemble, forment les zones d'hypertonie à la pointe des villosités; de la production, de la différenciation, du mouvement en escalier roulant (depuis la crypte jusqu'à la pointe de la villosité) et de l'exfoliation consécutive des cellules épithéliales de l'intestin. (Sont exclus les mécanismes neurohormonaux qui régulent le transport normal des ions dans la muqueuse.) On verra comment Vibrio cholerae, plusieurs pathotypes d'Escherichia coli, plusieurs sérotypes de Salmonella, les rotavirus, les espèces Campylobacter, Shigella dysenteriae, les espèces Yersinia et Clostridium difficile perturbent ces mécanismes et causent de la diarrhée. L'accent sera mis tout au long de l'article sur les études expérimentales visant à élucider les mécanismes biologiques et, s'il y a lieu, les déterminants microbiens responsables de la diarrhée. On tiendra compte aussi, au passage, des réactions de l'hôte comme l'inflammation, la production et la libération de cytokines puissantes ainsi que l'accélération des réactions homéostatiques, par exemple l'augmentation de vitesse de la division cellulaire dans les cryptes observée dans certaines infections, et du rôle que jouent ces réactions dans la sécrétion physiopathologique des liquides.

This mini-review was prepared from a presentation made at the World Congress of Gastroenterology, Vienna, Austria, September 6 to 11, 1998

Molecular Microbiology and Cell Biology Group, School of Biological Sciences, The University of Birmingham, Edgbaston, Birmingham, United Kingdom

Correspondence and reprints: Dr J Stephen, Microbial Molecular Genetics and Cell Biology Group, School of Biological Sciences, The University of Birmingham, Edgbaston, Birmingham B15 2TT, United Kingdom. Telephone +44-(0)-121-414-6550, fax +44-(0)-121-414-5925, e-mail J.Stephen@bham.ac.uk

Received for publication November 28, 1999. Accepted November 29, 1999 
$\mathrm{T}^{\mathrm{t}}$ is difficult, indeed unwise, to engage in meaningful discussion on the pathogenesis of infectious diarrhea without first considering the basic nature of the systems that, when perturbed, give rise to the pathophysiological state of diarrhea. It is also true that, in some cases (eg, diarrhea caused by enteropathogenic Escherichia coli [EPEC]), a great deal is known about the detailed molecular biology of initial attachment and the induction of ensuing cytopathology, but very little is known about the pathophysiological correlates that give rise to disease. In other cases (eg, diarrhea caused by rotavirus), a great deal is known about the pathophysiological responses giving rise to the disease, but very little is known about the pathogenic mechanisms triggering those responses. This mini-review reflects these different emphases. It is also written from an experimental, not a human clinical, standpoint.

\section{GUT PHYSIOLOGY: STRUCTURE AND FUNCTION}

One of the main functions of the gut is the selective active inward transport of ions and nutrient solutes that is followed by the passive movement of water. Highly simplified schematic representations of a small intestinal villus and of fluid uptake and physiological secretion are shown in Figures 1 and 2. The driving force is sodium/potassium ATPase situated in the basolateral membrane of entero-

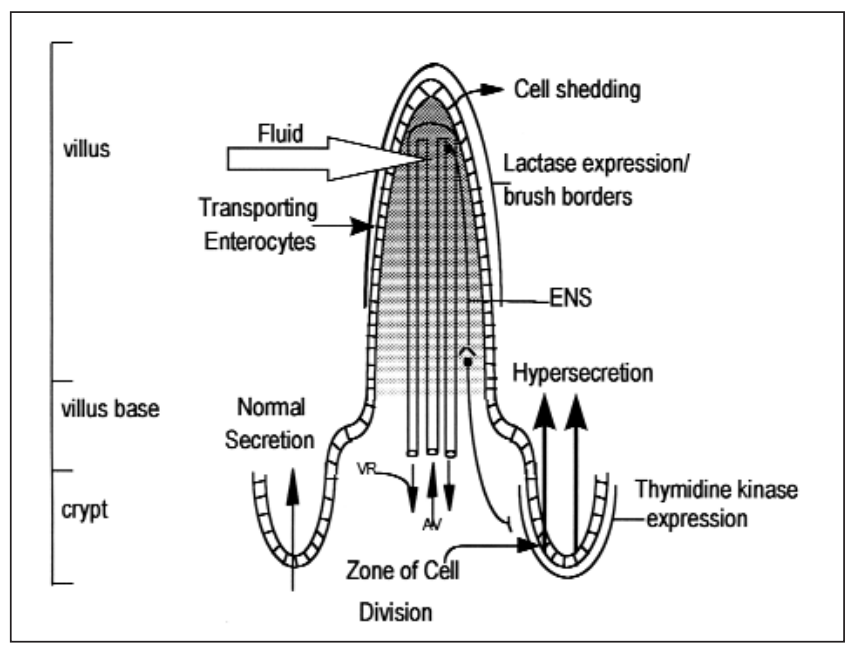

Figure 1) Simplified schema: integrated structure and function of the small intestinal villus. Note the central arterial vessel (AV), which arborizes at the tip into a capillary bed drained by a subepithelial venous return (VR). Movement of sodium into the VR creates a concentration gradient between $V R$ and $A V$, causing absorption of water from $A V$ and surrounding tissue. This results in a progressive increase in the osmolarity of incoming blood moving into the tip region through to the VR. Tip osmolarity is about three times higher than normal. Hyperosmolarity has been demonstrated in humans and can be inferred in mice from the morphology of erythrocytes, which changes during ascent of the same vessel from the base to the tip regions of the villi (see Figure 3). The shaded areas indicate a vertical increase in osmolarity. The left crypt represents normal physiological secretion; the right crypt represents hypersecretion. ENS Enteric nervous system (depicted schematically and not anatomically). Reproduced with permission from reference 98 cytes, which maintains a low intracellular sodium concentration and a high regional sodium concentration in the intercellular spaces, thus creating the electrochemical gradient favourable for sodium ion entry; chloride ions follow sodium ions. Sodium/potassium ATPase also drives secretion in crypt cells. The key difference is the location of the carrier systems responsible for the facilitated entry of the actively transported species. In villus cells, the carriers are present in brush borders, whereas in crypt cells they are located in basal membranes. This is responsible for the vectorial aspects of ion/fluid traffic in villus/crypt assemblies. However, it is clear that several factors in addition to enterocytes are involved in regulating fluid transport in the gut, including the enteric nervous system (ENS) and the anatomy of the microcirculation. The latter plays a profoundly important role in the uptake of fluid. At the tips of villi, osmolalities ranging from 700 to $800 \mathrm{mOsm} / \mathrm{kg} \mathrm{H}_{2} \mathrm{O}$ have been demonstrated in the human gut (1), which gen-

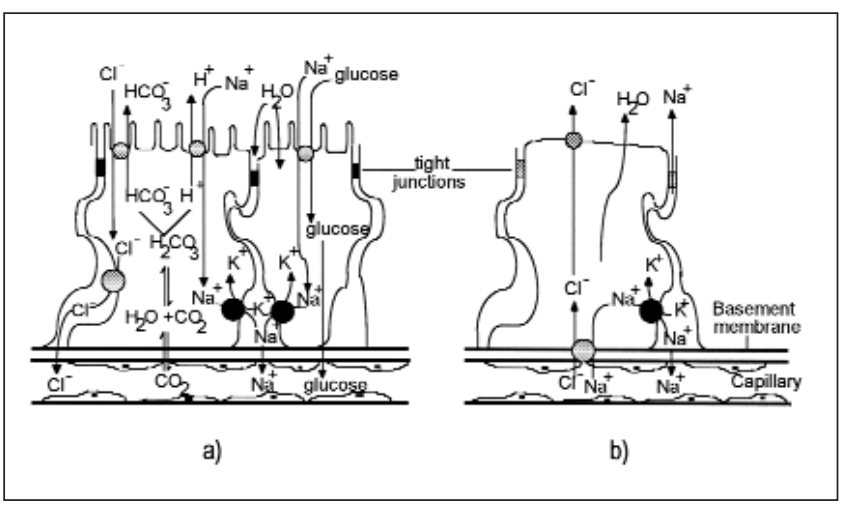

Figure 2) Simplified schematic representation of electrolyte transport by ileal mucosal tissue and its consequence for absorption (a) and secretion (b). Active processes involve the movement of ions and nutrient solutes; water follows passively. a) Two methods of sodium ion cotransport are shown involving a glucose-linked symport and two coupled antiports; one of the latter results in the cotransport of chloride ions. The coupled antiports are functionally linked via hydrogen and bicarbonate ions, the relative concentrations of which are a reflection of metabolic activity. These processes occur within the same cells but are shown separately for clarity. The driving force for sodium ion uptake is the low sodium ion concentration maintained by the sodium/potassium pump (ATPase) in the basolateral membrane, which creates the electrochemical gradient that promotes the inward movement of sodium ions; chloride ions follow sodium ions by diffusion. Water is drawn osmotically across the epithelium paracellularly (ie, across tight junctions) and/or transcellularly, the former pathway accounting for approximately $80 \%$ of fluid movement. b) Secretion is the result of the coupled entry of sodium and chloride ions across the basolateral membrane. Sodium ions are recycled by the sodium/potassium pump and chloride ions exit by diffusing down an electrochemical gradient and across the undifferentiated crypt cell apical membrane; sodium ions follow chloride ions, and water follows passively. Note: The driving force results from the same mechanism that powers absorption, ie, the sodium/potassium pump located in the basolateral membrane; it is the location of the 'port' 'diffusion' systems that determines the vectorial aspects of ion movement. The tight junctions are less tight in the crypts than in the villi. The apical membrane of the crypt cell is undifferentiated and only acquires microvilli during ascent into villous regions. - Na+/K+ pump; - Symport, antiport or diffusion channel 

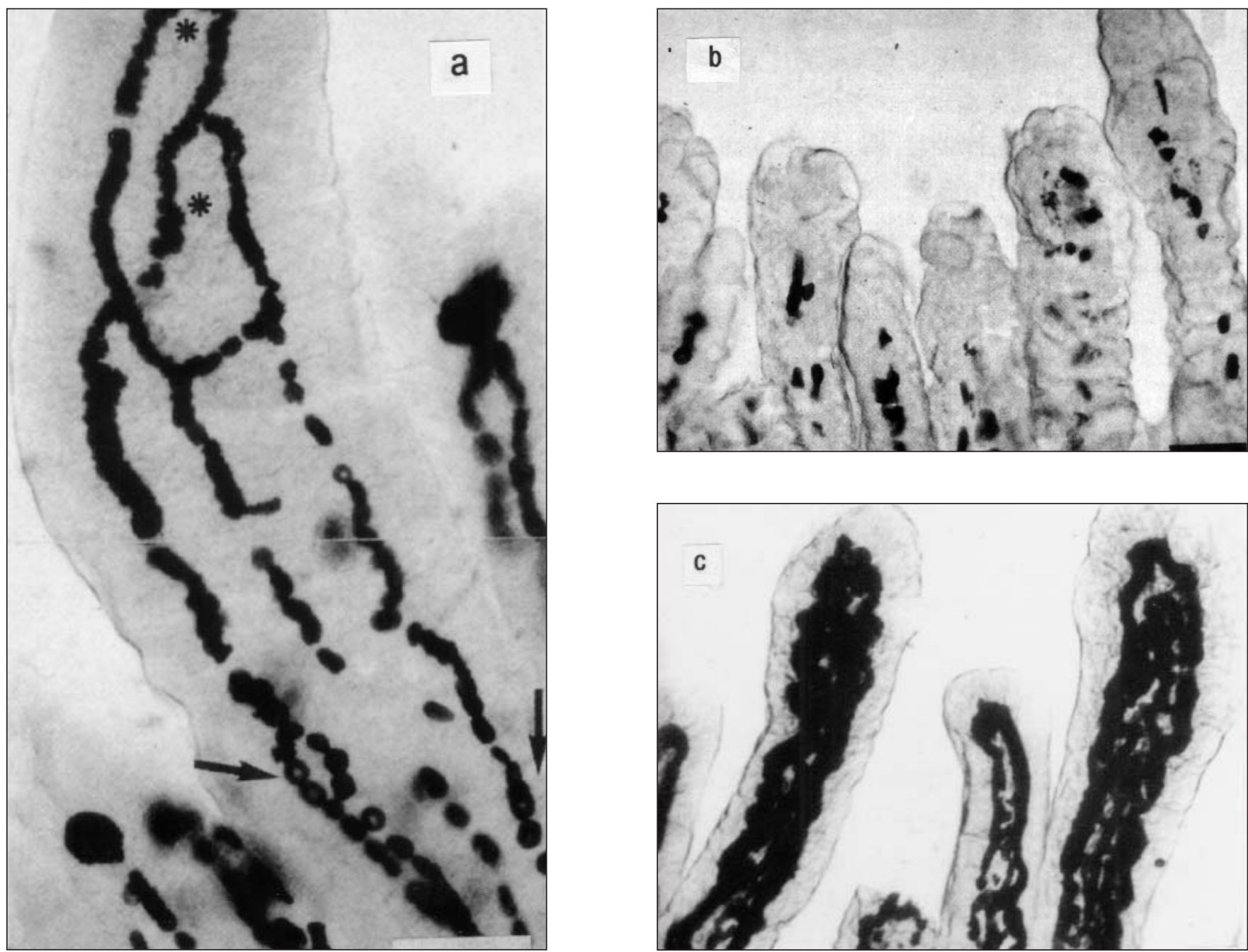

Figure 3) Villus circulation in neonatal mice. Whole collapsed villi isolated, fixed and stained as in references 2 and 3. a) Lower intestine of a normal eight-day-old mouse. Note the crenated cells (asterisks) in the apical region of the villus and the discoid red cells (arrows) in the basal region; scale bar $=60 \mu \mathrm{m}$. Reproduced with permission from reference 2. b) Villi of neonatal mouse, $48 \mathrm{~h}$ after infection with mouse rotavirus, are short, shrivelled and markedly ischemic; scale bar $=150 \mu \mathrm{m})$. c) Villi of neonatal mouse, $96 \mathrm{~h}$ after infection with mouse rotavirus. Vascular beds are distended and engorged with red blood cells (hyperemic); scale bar $=150 \mu \mathrm{m}$. Reproduced with permission from reference 2. Reproduced with permission from reference 3

erates huge osmotic forces. Thus, current perceptions are that enterocytes are responsible for generating this gradient (Figure 2) and that the blood supply acts as a countercurrent multiplier, which amplifies the gradient in a manner analogous to the loops of Henle in the kidney. The hypertonic zone has been demonstrated directly in whole villi of infant mice by the changing morphology of erythrocytes (2,3; Figure 3$)$; in the lower regions of villi, they show characteristic discoid morphology, whereas in the upper region they are crenated, indicating a hyperosmotic environment. The hypertonicity is dissipated if the blood flow is too slow and washed out if too fast. It is the villus unit rather than enterocytes by themselves that is responsible for fluid uptake. Another consequence of the microcirculatory anatomy is that the villus tip regions are relatively hypoxic.

Villus tips and crypts are regarded as the anatomical sites of physiological absorption and secretion, respectively. Fluid transport is a bidirectional process in the healthy ani- mal, with net absorption in health and net secretion in disease. The proximal small intestine is relatively leaky; in contrast, the terminal ileum and the colon are powerfully absorptive organs. The balance between absorption and secretion is poised at different points throughout the intestinal tract, which reflects differences in both structure and function of gut mucosal epithelia. Overall control of normal physiological ion/fluid movement is a highly complex phenomenon; for a review of the mechanisms underlying the neural and hormonal regulation of mucosal ion transport in the pig intestinal tract see reference 4 .

Intestinal epithelia are themselves dynamic structures that undergo complete turnover in approximately three to five days. Crypts are the principal sites of cell regeneration, and villus tips are the sites from which senescent cells are shed to be replaced with cells of crypt origin. Cells differentiate into absorptive enterocytes while migrating up the epithelial escalator. 

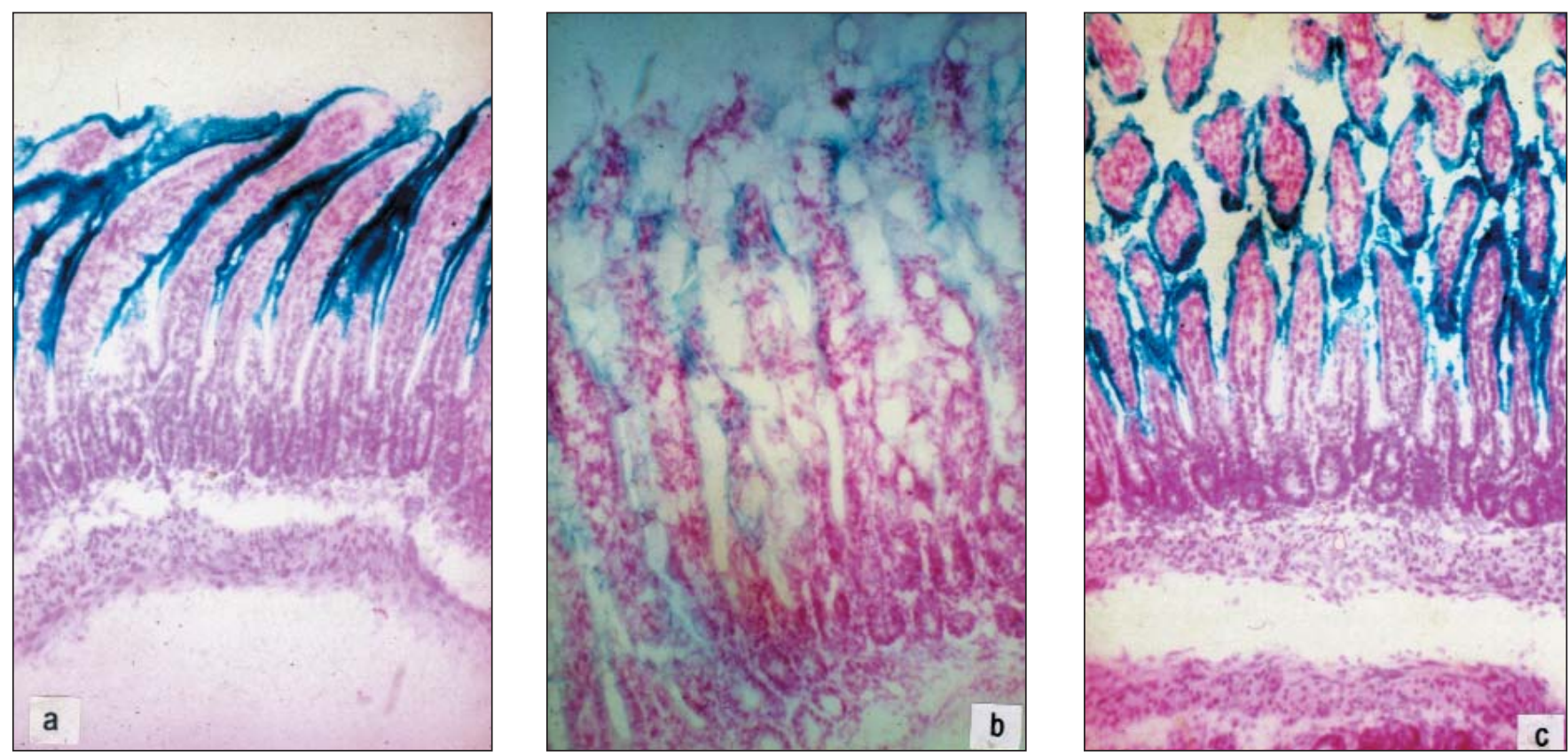

Figure 4) Lactase expression in the villi of neonatal mice. Frozen sections of neonatal mouse gut stained, fixed and counterstained as described by Collins et al (5). Lactase appears blue, and the rest of the tissue appears red. a) Ten-day-old normal mouse. b) Neonatal mouse $72 \mathrm{~h}$ after infection with mouse rotavirus. Note the residual traces of blue staining indicative of lactase. c) Recovery of lactase expression $120 \mathrm{~h}$ after infection with mouse rotavirus

Finally, in addition to the systems outlined above, neonatal brush borders contain disaccharidases (principally lactase [Figures 1 and $4 \mathrm{a}]$ ), which break down otherwise nonabsorbable disaccharides (eg, lactose) into constituent absorbable monosaccharides (5). As discussed below (see section on rotavirus), excessive loss of disaccharidase function may lead to an osmotic purge arising from nonabsorbed lactose.

Diarrheal disease can result from interference with almost any one or combination of these systems, as the rest of this article seeks to illustrate.

Vibrio cholerae: $V$ cholerae colonizes the upper small intestine by adhering to epithelial cells. Despite being arguably the most studied pathogen over the past three decades, the basis of $V$ cholerae pathogenicity and the detailed mechanisms underlying the dramatic diarrheal secretion induced by this organism are still not fully understood. Recently, spectacular advances have been made in the molecular biology of $V$ cholerae (6). Chromosomal DNA of virulent $V$ cholerae contains two essential genetic elements that are important in $V$ cholerae virulence: CTX $\phi$ (the genome of a filamentous bacteriophage), which encodes the cholera toxin (CT), and a large pathogenicity island, the $V$ cholerae pathogenicity island (VPI). VPI is now known to be the integrated genome of another large filamentous bacteriophage (VPI $\phi)$ and encodes the toxin coregulated type IV pilus (Tcp) (6). Of the numerous colonization factors known to be produced by $V$ cholerae (7), only $T c p$ has been proven to be important in human disease (8). Tcp is a remarkable entity; its subunit $\mathrm{Tcp}_{\mathrm{c}} \mathrm{A}$ is a coat protein of VPI $\phi$, but it also acts as a receptor for CTX $\phi$ and mediates interbacterial adherence (6). Thus, as a result of sequential infection by two 'pathophages', $V$ cholerae acquires the ability to colonize the human gut and secrete classical CT, which is a potent enterotoxin. The integration into the chromosome of these phage genomes brings their expression under the control of regulatory genes in the ancestral chromosome, while the replication of phages enables their interbacterial spread.

$\mathrm{CT}$ is an 'AB' type toxin in which the pentameric B subunit recognizes and binds to its cell receptor (GM1 ganglioside), thereby initiating the internalization of the active $\mathrm{A}$ subunit (CTA). The enzymatically active $A$ reaches its intracellular target by 'co-opting the molecular machinery used by the host cell to sort, move and organize cellular membranes and substituent components' (9). The activity of CTA is well known: it catalyses the ADP-ribosylation of the regulatory alpha subunit of adenylate cyclase, causing the elevation of cAMP. This in turn gives rise to a biochemical cascade, resulting in the perturbation of ion transport systems and the reversal of net ion transport/fluid across epithelial cells. This summary statement of such elegant work implies that cholera diarrhea is a purely pathophysiological disease, but that is too simplistic.

While the major diarrheagenic toxin is undoubtedly classical CT, there are at least eight other toxins that have been potentially implicated in cholera diarrhea (7). There is some evidence of involvement in human disease for one of these. A zonula occludens toxin of $V$ cholerae has been described, which alters the permeability of rabbit epithelia $(10,11)$. It has been suggested that the zonula occludens toxin might be responsible for the alteration in apical junc- 
tional complexes observed in human duodenal biopsies from cholera patients (12). However, it is the zonula adherens in human tissue and not the tight (occludens) junction that is affected by $V$ cholerae (12), and this emphasizes the care needed when extrapolating data from model systems to actual disease situations. Moreover, the studies on human jejunal biopsies show that cholera is not a purely pathophysiological disease but a pathological one involving changes in the microvasculature and enteric nerve fibres, degranulation of argentaffin cells, mucosal mast cells and eosinophils; the extent of these changes correlated with clinical severity of disease (12). A V cholerae vaccine strain produced by the deletion/mutation of all known toxin genes yielded a vaccine strain, which, though less reactogenic than wild-type virulent strains, still produced a significant diarrhea suggesting the involvement of an inflammatory component (as yet undefined) in the causation of cholera diarrhea (13). There is also experimental evidence to implicate the ENS in cholera diarrhea (14). It has also been shown (15) that CT administered to rat jejunum elicited a secretory response in both the jejunum and colon, which suggests neurological transmission of the locally induced secretory stimulus to distal colon.

E coli: It is essential to be reminded of the different pathotypes of $E$ coli, all of which, except for one (enteroinvasive E coli [EIEC], which is almost identical to Shigella species) are noninvasive. These pathotypes are enterotoxigenic E coli (ETEC); EPEC, which are characterized by localized adherence of organisms to HEp-2 cells; enterohemorrhagic $E$ coli (EHEC); two types of enteroaggregative $E$ coli (EAEC), which are characterized by aggregative adherence of organisms to HEp-2 cells and to each other in a stacked brick configuration; and diffusely adhering E coli (DAEC), which are characterized by diffuse monolayered adherence of organisms to HEp-2 cells. Because these different E coli pathotypes and the pathogenesis of disease they cause have been comprehensively reviewed (16), only a brief general outline is given here, with newer developments being highlighted. Uropathogenic E coli (UPEC) is referred to only in passing, and EIEC is not dealt with separately because of its relatedness to Shigella species. Necrotoxigenic E coli (17) are also excluded from this review.

ETEC: ETEC are the most common cause of diarrhea in children in developing countries and in travellers to these areas, and an important pathogen of weanling animals. Clinically, disease can range in severity from mild self-limiting to severe life-threatening cholera-like diarrhea. The pathogenesis of ETEC infection is largely explicable in terms of two important virulence attributes: the ability to adhere to epithelial cell surfaces and expression of enterotoxins.

Adhesion is mediated by 'colonization factors' ( $\mathrm{CFs}$ ), the nomenclature of which is very confusing. An attempt has been made $(16,18)$ to rationalize the situation for human ETECs by renaming them as coli surface antigens (CS, followed by a numeral, CS1, CS2 etc). E coli CFs are encoded on plasmids (which may also contain the genes for both types of enterotoxins described below), and determine both host and tissue specificity of infection. For example, important CFs produced by animal ETEC are not found on human strains, and CF K88 is found only in strains that infect pigs, whereas K99-expressing strains infect calves, lambs and pigs. CSs of human strains have been subdivided into four groups on a morphological basis - rigid rods, bundle forming, fibrillar and nonfibrillar (16) - the structures of which have been schematized (18). Tissue tropism is best illustrated by the specificity of interaction exhibited by UPEC in which its 'P' fimbria interacts with the Gal( $\alpha 1-4)$ gal oligosaccharide of the gycolipid part of blood group substance P expressed on uroepithelial cells.

Once ETECs have colonized, they produce enterotoxins, which can be of two types. Heat labile toxin (LT) is structurally and functionally homologous to CT and exists as two major antigenic groups (LT-I and LT-II), each of which has minor antigenic variants. In addition to LT, ETEC produces heat stable toxins (STs), which are nonantigenic, low molecular weight, cysteine-rich peptides that activate membrane-spanning guanylate cyclase, which causes the production of cGMP (a functional equivalent of cAMP), giving rise to a biochemical cascade resulting in the perturbation of ion transport systems as described above for CT. There are two unrelated classes of ST (STa [ST-I] and STb [ST-II]) encoded by plasmids (predominantly) and transposons. STa homologues are also produced by some strains of Yersinia enterocolitica and V cholerae non-O1. Another ST is produced by EAEC (enteroaggregative $E$ coli heat-stable enterotoxin 1 [EAST1], see below) and it too may be produced by some strains of ETEC. ST-I enterotoxins may represent a class of long-lived superagonists of guanylin, a regulatory intestinal peptide (19).

EPEC: Like ETEC, EPEC is essentially a pathogen of the small intestine. In the case of EPEC, and to a lesser extent EHEC, a similar situation exists to that described above for $\mathrm{V}$ cholerae. There has been a recent explosion of new molecular biological data $(20,21)$; an appreciation of the biological significance follows. EPEC was the first serotype of $E$ coli to be incriminated as a pathogen. Its designation as EPEC is unfortunate because all pathogenic $E$ coli are in a real sense enteropathogenic, but the nomenclature is rigidly embedded. It is essentially a noninvasive pathogen with only rare reports of its presence inside human gut epithelial cells (22); it can, however, be internalized by cultured cells (20). The pathognomonic lesion of EPEC is the pedestal type 'attaching and effacing' (A/E) lesion induced on microvillibearing enterocytes, resulting in 'intimate' type of adherence (Figure 5). There are two main genetic elements that confer virulence on EPEC: bfp genes (bundle forming pili $[\mathrm{BFP}]$ encoded in the EPEC adherence factor $[\mathrm{EAF}]$ plasmid) and the genes encoding the determinants of $\mathrm{A} / \mathrm{E}$ encoded in the chromosomally located locus of the enterocyte effacement (LEE) pathogenicity island. BFP have been shown in human volunteer studies to be important, although not absolutely necessary, in the colonization of EPEC; their expression is regulated by the per (plasmid- 


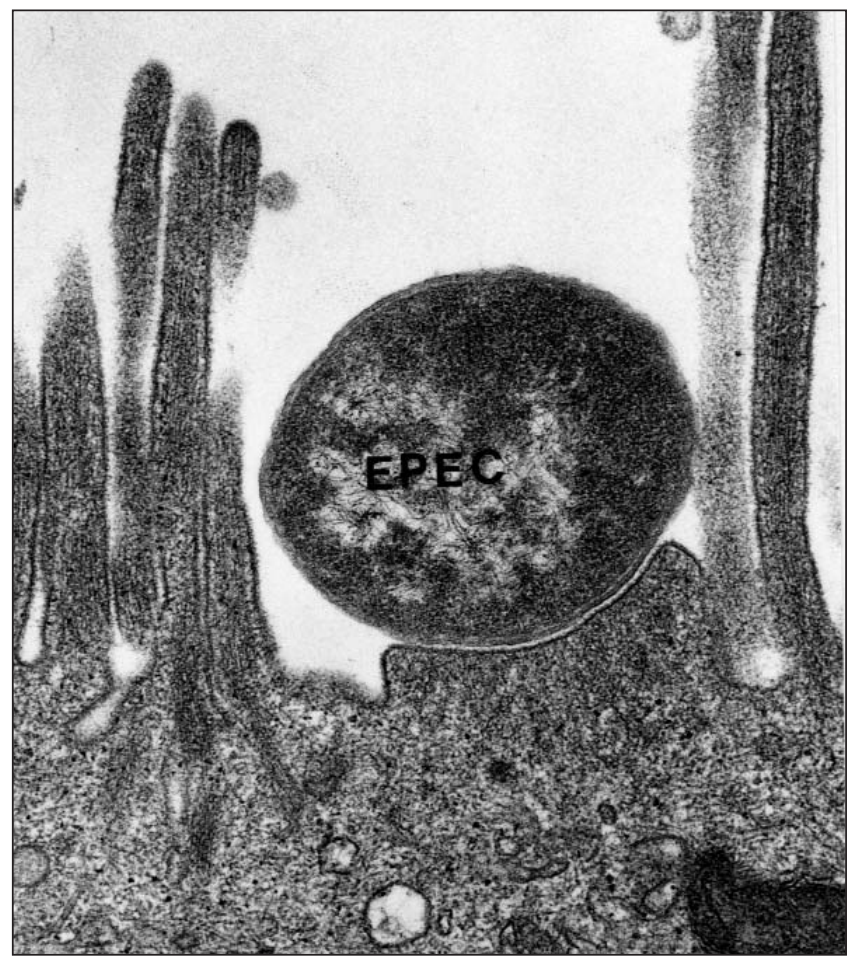

Figure 5) Enteropathogenic Escherichia coli (EPEC) intimate adhesion. Reproduced with permission from reference 100

encoded regulator) genes located in the EAF plasmid. The per regulator also controls expression of other membrane proteins and thus acts as a global regulator, a feature now increasingly recognized in pathogenic bacteria. Upon contact with epithelial cells, expression of LEE is triggered. A speculative synthesis of the genetic and ultrastructural data suggests the following (Figure 6). Initial contact of EPEC with epithelial cells is via BFP. Bacterial/target cell contact triggers expression of an LEE-encoded type III secretion system, resulting in the secretion of different subsets of proteins with different functions. (There are at least four mechanisms for secreting proteins from Gram-negative bacteria, designated types I, II, III and IV [23]). Organisms known to have the type III system include Yersinia, Shigella, E coli and Salmonella species. Its main features are that it is expressed in response to an environmental signal such as contact with eukaryotic cell membranes; it translocates proteins from bacterial cytoplasm across cytoplasmic and outer membranes; and in some cases a subset of type III-secreted proteins are assembled into a 'translocon' apparatus or 'molecular syringe' for delivering other effector proteins into epithelial or phagocytic target cells. Some are involved in the synthesis of the 'translocon' apparatus constructed from proteins that form pores in both the bacterial outer membrane and the host cell membrane. These pores are connected by a cylindrical structure comprising other LEEencoded proteins, and the whole structure acts as a molecular syringe through which bacterial translocated intimin receptor (Tir) is inserted into the host cell membrane. Together with a host cell coreceptor, Tir interacts with the

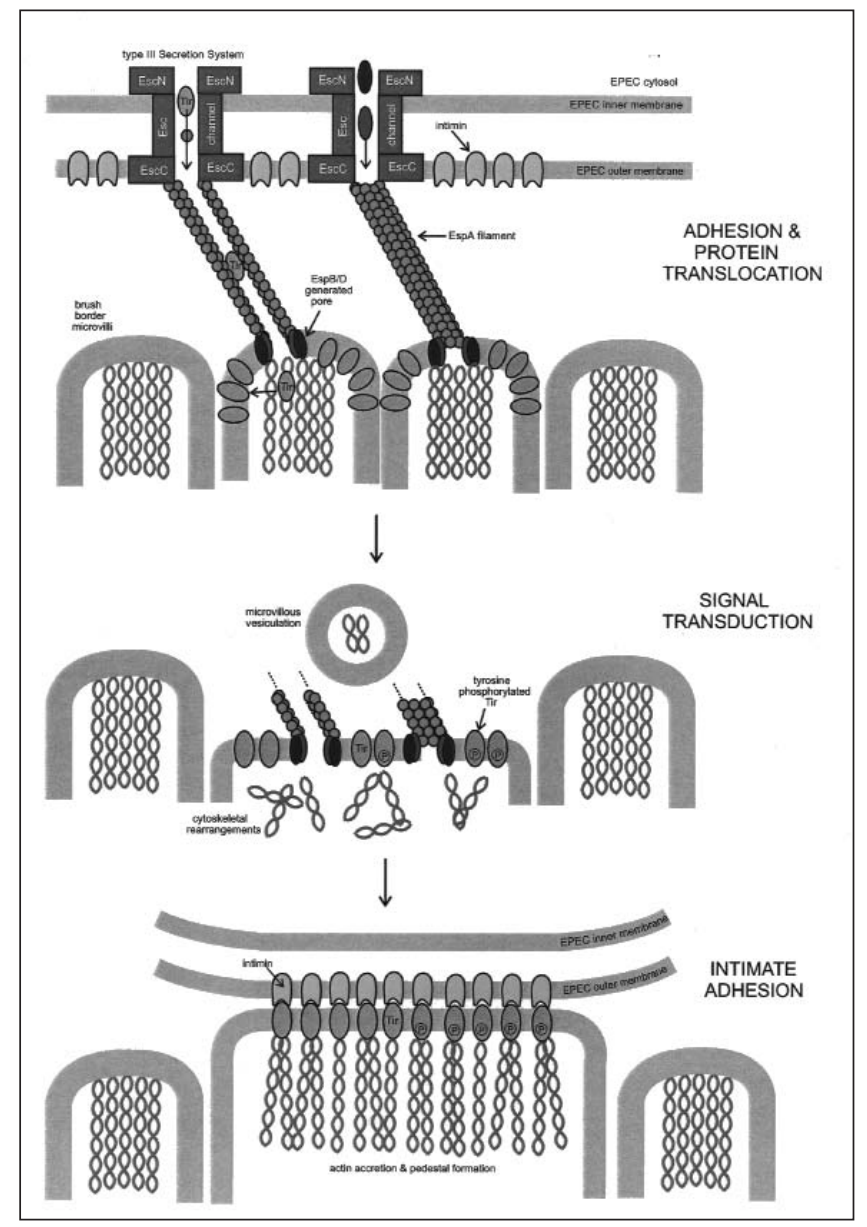

Figure 6) Schematic representation of the molecular events giving rise to the enteropathogenic Escherichia coli (EPEC)-induced pedestal. Reproduced with permission from reference 20. ESc E coli secretory proteins forming part of the type III secretion system; Esp E coli secreted proteins; Tir Translocated intimin receptor

EPEC outer membrane protein intimin, resulting in the intimate binding of the bacterium to the cell membrane, which gives rise to the characteristic pedestal and deformed brush border (24). Tir is thus a multidomain protein; interaction with intimin results in cytoskeletal rearrangement of the host cell, the formation of the characteristic pedestal and the transduction of signals leading to fluid loss. Such brilliant molecular biological studies have taken us thus far, but no further; the specific signal transductions, how precisely they are generated and how they act to cause diarrhea are not known. However, the dramatic onset of diarrhea seen in volunteer studies $-2.9 \mathrm{~h}$ after ingestion of bacteria (25) - strongly indicates the involvement of an active secretory mechanism. The prolonged diarrhea could well be due to the loss of functional brush border, where the transport systems are located. The significance of EAST1, found in some strains of EPEC is not known (16).

EHEC: Since the early 1980s, EHEC has become a cause celebre with E coli 0157:H7 - a familiar household fearinducing term. There are striking similarities between EPEC and EHEC. The most obvious similarity is the ability 
to form the intimate type of adhesion pedestal; the A/E lesion is readily demonstrable in conventional and gnotobiotic pigs, infant rabbits and cultured cells, but not in humans because this facet of the disease occurs early and biopsies are taken (and only when clinically warranted) later in the infection when $\mathrm{A} / \mathrm{E}$ lesions would be missed. EHEC possesses LEE, the genetic organization of which is the same in both EPEC and EHEC, with 93.9\% average nucleotide identity. However, the gene encoding intimin is less conserved ( $87.23 \%$; see below), and those encoding the secreted proteins including Tir are quite divergent (20). Such analyses are of more than mere academic interest because an understanding of the biochemical basis of the host and tissue specificities exhibited by pathogens provides a basis for effective vaccine development. However, there are significant differences between EPEC and EHEC.

Unlike EPEC, EHEC is essentially a pathogen of the large intestine. It is now known that intimin is not a single molecular entity but a family comprising at least four antigenically distinct subtypes - alpha, beta, gamma and delta. The divergent $\mathrm{C}$-termini of these multifunctional intimins contain the cell-binding domains (21). This diversity had been proposed as an explanation for the tissue tropism exhibited by EHEC, which shows a predilection for colonizing the colon as opposed to the small bowel. These ideas were given credence by the demonstration of an ability to alter the site(s) of colonization of EHEC in gnotobiotic pigs by substituting EPEC genes for their equivalent in EHEC. However, it is unlikely that tissue specificity is explicable in terms of intimin-Tir interaction, if for no other reason than that the main receptor for intimin, Tir, is itself a bacterial protein. Recent detailed structural and genetic studies on intimins show intimin to comprise three separate domains: two immunoglobulin-like domains and a C-type lectin-like domain (26). From detailed intimin-Tir studies (21), it was concluded that intimin-Tir interaction cannot explain tissue/species specificity; it is more likely that tissue tropism is determined by an initial lectin-like recognition of a specific cell receptor by intimin. Other systems may also be involved because some strains of $E$ coli have been isolated from human cases of hemolytic uremic syndrome (HUS), which belong to serotypes other than O157:H7 (16). Another important difference between EHEC and EPEC is that EHEC does not possess EAF, hence no per gene homologues; the regulation of LEE in EHEC is not known (20). The vast majority of EHEC strains possess a $60 \mathrm{MDa}$ plasmid, which also encodes an enterohemolysin and a fimbrial antigen, but the significance of these and other plasmidencoded genes in the pathogenesis of EHEC-induced disease is unclear at present (16).

Easily, the most important distinguishing feature of EHEC is the capacity to progress disease beyond the watery diarrhea stage to a grossly bloody diarrhea (hemorrhagic colitis [HC]) and HUS, which is characterized by renal failure, thrombocytopenia and microangiopathic hemolytic anemia. This virulence attribute is due to possession of one or more of a family of Shiga toxin(s) (Stx), which are encoded by lysogenic lambdoid phages. Stx1 is identical to Stx of Shigella dysenteriae I (which is not phage encoded) and is highly conserved, whereas a variety of subtypes of Stx2 exist. The role of Stx in the causation of watery diarrhea is controversial, and it may not be absolutely necessary. However, there is no doubt that Stx is either responsible for, or severely exacerbates the bloody diarrhea in HC. Sjogren et al (27) orally challenged young rabbits with rabbit diarrheagenic E coli (RDEC-1) (a rabbit strain of EPEC) and an Stx-positive RDEC-1 derivative; the disease resulting from the Stx-positive strain was much more severe. This echoed earlier work (28) in which monkeys were orally challenged with wild-type $S$ dysenteriae I and a Stx-negative derivative of $S$ dysenteriae I. In both groups, diarrhea occurred, but with the wild-type strain, there was distinctly greater tissue hemorrhage and more bloody stools. Unfortunately, there are no suitable animal models for HUS, but a body of persuasive indirect evidence has been marshalled, which implicates Stx as the principal causative agent of HUS (16). More importantly, others have recently made the first histochemical demonstration of both Stx1 and Stx2 bound to renal tubules in the kidney of a child who died as a result of HUS associated with E coli O157:H7 infection (29).

EAEC and DAEC: In comparison with the previously discussed E coli pathotypes, the pathogenesis of EAEC and DAEC infections are much less well understood. The characteristic histopathological feature induced by EAEC is the aggregation of bacteria entrapped within a mucous gel, accompanied, not surprisingly, by pitted goblet cells. In volunteer studies, diarrhea was predominantly mucoid (16). Genes encoding EAEC adhesins and EAST1 have been identified on a $60 \mathrm{MDa}$ plasmid. Another cytotoxin has been recognized of as yet unknown biological significance. Even less is known about the pathogenesis of DAEC infection, but the separation of DAEC into a separate subclass of diarrheagenic $E$ coli is apparently confirmed by the isolation of genes that mediate the diffuse monolayered type of adherence (16).

Salmonella species: In this section, Salmonella species are dealt with under two headings, which reflects a recent perception that there are at least two invasive biotypes of this pathogen that cross conventional serotypic boundaries.

Salmonella species are an example of a diarrheagenic pathogen, some strains of which actually cause the detachment of epithelial cells. Arising from combined quantitative and electron microscopic studies of the invasiveness of various Salmonella strains, both in vivo in rabbits, pigs and calves, and in vitro in explants of rabbit terminal ileum, it is clear that Salmonellae species can be grouped as histotoxic or nonhistotoxic according to how they initially interact with the gut epithelium (30-35). A summary of the findings from our laboratory is given below.

Histotoxic Salmonella species: The main feature of the early damage to epithelia caused by histotoxic Salmonella species is a toxin-mediated detachment of enterocytes that is preceded by cleavage of tight junctions. This leads to the 
release of microvilli-bearing cells that degenerate rapidly into spherical highly vacuolated entities. The toxin may be an intracellularly acting cytotoxin that causes disruption of tight junctions and subsequent intracellular disorganization from the inside. Alternatively, it may act externally on tight junctions, with subsequent cytopathic changes occurring as a result of highly differentiated enterocytes being removed from their normal environment. Later in the infection, bacteria-laden cells that did not appear to be extensively vacuolated, were seen being shed, perhaps indicating that toxin activity is expressed intralumenally rather than intracellularly. Similar lesions were produced in rabbit tissues challenged in vivo and in vitro with live histotoxic Salmonella typhimurium and Salmonella dublin strains. Sterile supernates from rabbit gut challenged in vitro with histotoxic $S$ typhimurium strain GM3 induced an almost identical picture of epithelial disintegration when added to fresh tissue from the same animal. In calves and pigs, histotoxic $S$ dublin strain 3246 caused extensive tissue damage to both absorptive epithelium (AE) and follicle-associated epithelium (FAE). Salmonella serotype choleraesuis was not histotoxic in any experimental setting. These observations are of crucial importance in attempting to understand the pathogenesis of Salmonella infection. By virtue of their ability to denude epithelia, these organisms open up new routes of invasion and tissue transmigration. It was not difficult to demonstrate histotoxic $S$ dublin inside disintegrating cells near vascular elements of infected bovine tissues (34).

Non-histotoxic Salmonella species: Non-histotoxic Salmonella species are an example of a pathogen that causes shortening of whole villi (30). Here, the picture, as observed in the rabbit ileal loop model, is totally different from that described for histotoxic Salmonella species. Bacteria enter via brush borders, and bacteria-laden cells are shed. There is no evidence of a rapid initial cleavage of tight junctions. The time scale of events is quite different from that seen with histotoxic Salmonella species, with maximum cell shedding, leading to truncation of villi, occurring at 12 to $14 \mathrm{~h}$ after challenge. Behind the extrusion of bacteria-laden cells, the epithelium is resealed. By $18 \mathrm{~h}$, truncated villi appear 'normal', as judged by scanning electron microscopy, and begin to undergo reconstruction. Clearly, it is possible that, in such a situation, loss of the tip regions of villi could lead to loss of absorptive potential and hence contribute to secretion by unmasking, if not stimulating 'normal' secretion.

This extensive study of both histotoxic and nonhistotoxic Salmonella species has also thrown light on other aspects of the pathogenicity of this highly complex pathogen. First, we found no evidence for the idea that the host-restriction exhibited by Salmonella serotypes dublin and choleraesuis for cattle and pigs is explicable solely in terms of major differences in their respective invasiveness for terminal ileum.

Second, we found no evidence that entry of Salmonella species into the gut was obligatorily via $\mathrm{M}$ cells. There is now a growing acceptance, based largely on studies in murine-ligated loops, that $\mathrm{M}$ cells are the main primary route of the entry of Salmonella species into the gut in vivo. It is perceived that $\mathrm{M}$ cells then die, creating a gap in the epithelium through which bacteria can penetrate and then infect adjacent enterocytes via basolateral membranes, resulting in exfoliation of enterocytes, denudation of follicle-associated epithelium and exposure of the basement membrane to luminal bacteria (36). It is interesting to note that the damage seen in murine-ligated loops $2 \mathrm{~h}$ after infection (with very large doses of mouse virulent S typhimurium strain SL 1344 [36]), bears some similarity to that caused by histotoxic $S$ dublin strain 3246 in pigs, calves and rabbits $(34,35)$. It is possible that the disruption of murine epithelia (34) was toxin-mediated as distinct from being a secondary undefined consequence of $\mathrm{M}$ cell destruction. The 'M cell scenario' may hold for $S$ typhimurium in mice but certainly not in calves, where both $\mathrm{M}$ cells and enterocytes were infected very early in infection. In calves, infection of $\mathrm{M}$ cells and enterocytes occurred independently $(37,38)$, separated in time by only $10 \mathrm{~min}(38)$. In both calves and pigs, no preference was shown by Salmonella species for FAE over $\mathrm{AE}$ as judged by quantitative recoveries of organisms from samples taken from the same ligated intestinal loop (34). In the rabbit, Peyer's patches are discreet islands, and in all our work were avoided in the selection of ileal segments for both in vivo and in vitro experiments; Salmonella species readily invade enterocytes directly $(30,33)$. In pigs infected with Salmonella choleraesuis, it was possible to demonstrate the concurrent entry of organisms into both $\mathrm{M}$ cells and enterocytes, separated from each other in the same section (34).

Third, because the virulence of Salmonella species is multifactorial, the choice of model system is crucial. For example, $S$ typhimurium in the mouse is equivalent to Salmonella typhi in humans and, therefore, is not the best model for localized gastroenteritic infections caused by Salmonella species in humans. The rabbit ileal loop model (39) and the in vitro organ culture system derived from it (31) were chosen for a laboratory animal model for human disease caused by Salmonella species based on the work of Giannella and colleagues in the 1970s (see reference 40). But, if Caco-2 cells (which are gut-derived, tight junction-forming, microvilli-expressing cells) are used as model epithelia, the tight junction cleavage by Salmonella serotype dublin cannot be demonstrated, as was shown in vivo (41).

Fourth, the question of the number, nature and role of Salmonella toxins is still generally confusing. However, the histotoxin described above has been demonstrated to produce the same lesion in vivo and in vitro. In contrast, there is little evidence to implicate a CT-like enterotoxin in the causation of Salmonella-induced diarrhea in experimental infections of rabbits (39) or in calves (42).

Fifth, with virulent strains, fluid secretion was always accompanied by a massive influx of polymorphonuclear (PMN) cells. However, PMN influx per se was not sufficient to cause fluid secretion $(43,44)$. Finally, based on limited experimental data, the ability of nonhistotoxic Salmonella to induce fluid secretion was greater than histo- 
toxic Salmonella (35). It appears that it is the nature of the damage rather than the mere extent of the damage that determines the severity of the diarrheal response. As in an increasing number of areas in infectious disease, it is becoming clear that cytokines play an important but as yet unclarified role in the pathophysiological response leading to diarrhea (45).

In recent years, there has been a huge effort, still actively ongoing, to discover the molecular genetic basis of virulence of Salmonella. As a result, at least five 'pathogenicity islands' have been recognized in the Salmonella chromosome. For general reviews on this fast moving topic, the reader is referred to references 45 and 46 . It is beyond the scope of this review, and somewhat premature because the field is rapidly developing, to attempt a detailed coverage of this complex field in relation to Salmonella species, but a few emerging points are summarized. First, the genes recognized in these Salmonella pathogenicity island (SPI) clusters are mainly involved with invasion of eukaryotic cells, intracellular survival and systemic infection. Second, at least SPI-1 and SPI-2 are known to encode type III secretion systems. Some of the secreted proteins have been recognized and are involved in the translocation of effector molecules into eukaryotic target cells, thereby promoting invasion (46-51). Appendage structures have been observed whereby $S$ typhimurium attaches to gut epithelia $(52,53)$. These appendages are remarkably similar to those described for EPEC (20) but have not yet been fully characterized. It is only a matter of time before the Salmonella picture is developed to a similar extent as that already described above for EPEC and EHEC.

Rotavirus: In this section, a closer look is taken at the phenomenon of villus shortening and its consequences, and the subsequent host response of villus resynthesis. For this we draw on a multidisciplinary study of a naturally occurring infection of seven-day-old neonatal mice (rotavirus-antibody free) with the homologous murine epizootic diarrhea of infant mice (EDIM) strain of rotavirus. These studies were carried out from oral challenge (the natural route of infection), through a clinical peak of diarrhea that occurred $72 \mathrm{~h}$ after infection to resolution of the infection seven days later.

Quantitative measurements of virus infection in different regions of the gut showed that virus production was biphasic, peaking at $48 \mathrm{~h}$ with a second peak at $120 \mathrm{~h}$. Virus was located in the upper regions of mainly mid-small intestinal villi, although the upper and lower small intestines were also infected, but not the colon (54). Maximal diarrhea did not coincide with peak of virus production.

Transmission and scanning electron microscopic study of changes in gut villi showed constriction of villus bases with edema of the lamina propria, and vacuolation of enterocytes $24 \mathrm{~h}$ after infection, that is before the peak of virus replication (55). The virus was not by itself inherently cytopathic, as was readily demonstrated at later time points in the infection. Enterocyte damage was perceived to be the consequence of tissue hypoxia as discussed below. By $48 \mathrm{~h}$

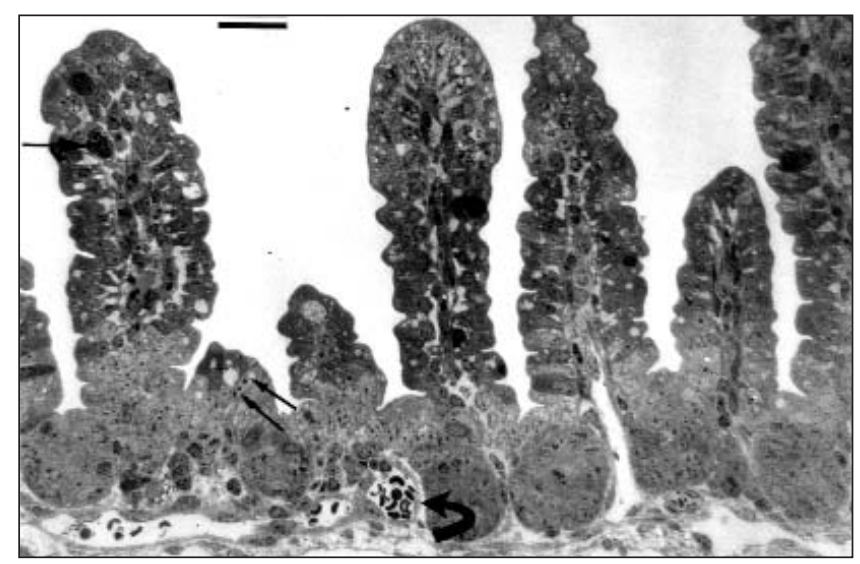

Figure 7) Transmission electron micrograph of neonatal mice $72 \mathrm{~h}$ after infection with mouse rotavirus. Low power transmission electron micrograph showing longitudinal sections of several villi from small intestine of mouse $72 \mathrm{~h}$ after infection with mouse rotavirus. Most enterocytes in the upper regions of villi are electron opaque, vacuolated and obviously damaged. Cells at the villus bases are electron lucent and represent areas of cell replication; mitotic profiles were visible (small double arrows). Note the congested tip capillary (single arrow) and the patent subepithelial vessel (curly arrow). Reproduced with permission from reference 57. Scale bar $=25 \mu \mathrm{m}$

after infection, atrophy of villi occurred - their height being reduced by $50 \%$ to $60 \%$. Maximal diarrhea did not coincide with maximal atrophy of villi.

Both quantitative (56) and histochemical (5) studies of alkaline phosphatase, thymidine kinase (a marker for DNA synthesis and hence crypt cell activity), lactase (Figure 4), maltase, sucrase and sodium/potassium ATPase were undertaken. Three points emerged from these gut enzyme studies. First, while the levels of lactase fell, the residual level of lactase was demonstrably sufficient to handle most of the lactose load delivered from the stomach to the small intestine at $72 \mathrm{~h}$ after infection, the peak of clinical diarrhea. A corollary to this is that a child who becomes lactose intolerant must be suffering from severe erosion of intestinal villi over a significant length of the small bowel. Second, thymidine kinase levels peaked at $72 \mathrm{~h}$ after infection, at which point cell division in the villus base region was increased (57) (Figure 7). Villus reconstruction also took place rapidly between 48 and $72 \mathrm{~h}$ after infection. Third, based on the accelerated appearance of sucrase in the reconstructed gut, it is unlikely that prolongation of diarrhea was due to the presence of 'immature' absorptive cells; an alternative explanation for prolonged secretion can be given in terms of altered villus microcirculation (see below). Confirmation of the secretory state of the gut was obtained by in vitro studies, which showed that the gut was maximally secretory $72 \mathrm{~h}$ after infection $(58,59)$.

Remarkable changes occurred in the microcirculation of rotavirus-infected mouse intestine (2,3). Between 18 and $48 \mathrm{~h}$ after infection, villi became ischemic and atrophied throughout all areas of the small intestine. By $72 \mathrm{~h}$ after infection, villi had recovered their normal height and 

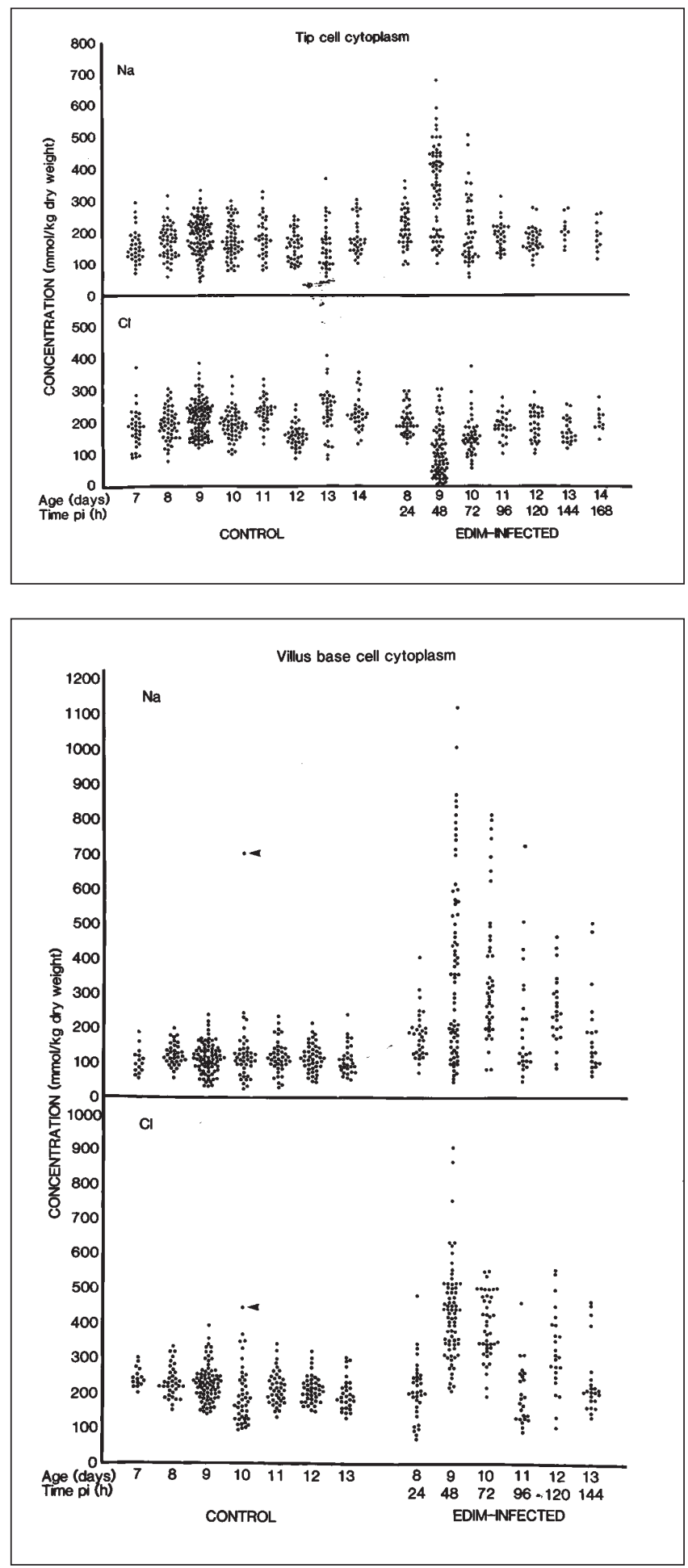

Figure 8) X-ray microanalysis of neonatal mouse gut before and during infection with mouse rotavirus; sodium and chloride ion profiles. The analyses were performed in regions corresponding to the tips of villi (top), the translucent band of villus base cells (bottom) and crypt regions (Figure 7). No significant changes were observed in crypt regions (not shown). Striking changes were observed in villus bases of infected mice, in particular at 48 to $72 \mathrm{~h}$ after infection, concomitant rises in both sodium and chloride ions were observed. In contrast, in villus tips, sodium levels rose while chloride levels dropped at $48 \mathrm{~h}$ after infection. The arrow heads in the villus base panels indicate data from a dividing cell in control tissue. EDIM Epizootic diarrhea of infant mice. Reproduced with permission from reference 60 showed incipient hyperemic microcirculation. At $96 \mathrm{~h}$ after infection, hyperemic microcirculation was most marked. Between 120 and $144 \mathrm{~h}$ after infection, a second phase of villus atrophy occurred, which was more attenuated and confined to the upper and middle regions of the intestine. This phase was not accompanied by a widespread ischemia of villi; a minority of villi were short and ischemic but many appeared hyperemic. Recovery of villus microcirculation occurred at $168 \mathrm{~h}$ after infection, which coincided with the reappearance of crenated erythrocytes and recovery from diarrhea.

Intracellular concentrations of elements were measured by $\mathrm{x}$-ray microanalysis in gut epithelia of infected mice (60). Although infection was limited to villus tip regions in the small intestine, significant changes in concentrations of sodium and chloride ions were observed (Figure 8), in both villus tip cells and villus base cells corresponding to the electron lucent cells in Figure 7.

The main conclusions of these integrated studies may be summarized as follows. First, the rapid onset of ischemia (triggered by an unknown mechanism) after initial entry of the virus causes hypoxia, cytopathic changes in enterocytes and hence atrophy of villi. These are precisely the kinds of changes induced by experimental ischemia (61). The ensuing increased rate of cell division, necessary for the reconstitution of villi, results in transient accumulation of high levels of sodium chloride in a population of villus base cells; a similar phenomenon was seen in dividing HeLa cells (62). (The phenomenon of villus shortening is often reported in histological analyses of ileal epithelia infected with a variety of pathogens. A corollary to this finding would be that resynthesis of truncated villi would be accompanied by the kind of elemental changes seen in the rotavirus-infected mice during the peak period of diarrhea. It is possible to infer that this actually happens in Salmonella-infected rabbits. Treatment with nitrogen mustard before infection, ostensibly to inhibit PMN influxes, resulted in massive invasion by Salmonella and damage to the epithelial tissue, but no fluid secretion (44). This result was interpreted in terms of the alkylating effect of nitrogen mustard on DNA and, hence, interference with crypt cell regeneration).

The loss of excess sodium chloride into the lumen induces hypersecretion of fluid. The rise in sodium and fall in chloride ion levels in the tip cells occurred when villi were ischemic and hence hypoxic. Hypoxia induces a switch to anaerobic/glycolytic-type metabolism, with a predictable rise in intracellular hydrogen ion concentration and a decrease in bicarbonate ion concentration, resulting from perturbation of the carbonic acid dissociation equilibrium. The ensuing imbalance in sodium/hydrogen, chloride/bicarbonate antiports would in turn imbalance the uptake of sodium and chloride ions; predictably, the intracellular sodium ion concentration would rise and the chloride ion concentration would fall (63). From this analysis, it would follow that the hypoxic state of the upper parts of newly synthesized villi is the reason for lack of absorption and not 'immature' enterocytes, and that the prolongation 
of diarrhea is associated with an intermediate hyperemic state. Only when blood flow had returned to normal did the tip hyperosmotic zone become re-established (demonstrated by a reappearance of crenated red blood cells similar to that shown in Figure 3) and diarrhea stopped.

Campylobacter species: While the clinical picture of Campylobacter jejuni infection, the transmission of the pathogen and epidemiology of disease are all fairly well understood, attempts to understand the genetic and molecular basis of the virulence of this pathogen and of the factors that poise the host toward susceptibility to infection and severity of clinical enterocolitic disease, are only beginning. The clinical picture of the pathogenesis of $\mathrm{C}$ jejuni infection has been summarized in a comprehensive review (64). C jejuni and related species are the most common bacterial causes of diarrhea in many industrialized countries. In developing countries, the most common clinical presentation is mild watery diarrhea, whereas in developed countries, disease often manifests as a severe inflammatory diarrhea. No evidence has yet been found to suggest that the watery type and severe bloody types of diarrhea can be explained in terms of a $\mathrm{C}$ jejuni equivalent of the ETEC and EHEC mechanisms described above. Current thinking proposes that the different disease patterns reflect the immunological status of the host. Those with full immunity experience no clinical disease, whereas those with no preimmunity experience the full blown bloody diarrhea and those with partial immunity, watery diarrhea $(64,65)$.

The incubation period can range from one to seven days, and acute diarrhea can last for one to two days with abdominal pain, which may persist after diarrhea has stopped. Diarrheal stools often contain fresh blood, mucus and an inflammatory exudate with leukocytes; bacteremia may also occur although it is rarely reported. Infected mucosae may be edematous and hyperemic with petechial hemorrhages. The disease, even its severe form, tends to be self-limiting, despite the fact that organisms may be isolated for several weeks after resolution of the symptoms. We do, however, know that there is a strong correlation between infection with $\mathrm{C}$ jejuni and Guillain-Barré syndrome, which is the most notable complication of $\mathrm{C}$ jejuni infection (65). Guillain-Barré syndrome is a peripheral neuropathy believed to be an autoimmune phenomenon arising from molecular mimicry between the polysaccharide side chains of $\mathrm{C}$ jejuni and neural gangliosides (66).

While there are reasonable models for studying colonization and initial invasion (65), there is a problem regarding experimental animal models in which to reproduce the extreme form of bloody diarrhea seen in humans. This constitutes a major reason why very little is known about the detailed mechanisms of pathogenicity of this hugely important pathogen. Most work to date has been carried out with in vitro cell systems (65) from which two new claims have been made. A novel mechanism for internalization of C jejuni into Caco-2 cells has been proposed involving caveolae, which are nonclathrin-coated plasma membrane invaginations to which several cell-signalling molecules have been localized (67). Others recently claimed to have demonstrated, for the first time, the equivalent of a type III system for secreting proteins into eukaryotic cells (68), but this interpretation of the data is not supported by reference to the complete genome sequence, which has recently been completed (69). However, the $\mathrm{C}$ jejuni situation is probably about to change dramatically. A new strategy has been outlined based on the use of the new technology of 'microarrays' (70). By this means, and by reference to the genomic atlas, it is theoretically possible to identify which genes are expressed under different sets of experimental conditions, including those that mimic the infection environment. Doubtless, a plethora of new data are about to be generated from which we hope to learn more of the disease-conferring attributes of $\mathrm{C}$ jejuni and related species.

$S$ dysenteriae: $S$ dysenteriae causes dysentery, an acute infectious rectocolitis resulting in low volume bloody diarrhea that is often preceded by a watery diarrhea phase. While the precise mechanism of watery diarrhea induction is not entirely clear, in particular the role played by Stx, the pathogenesis of the colitic phase of the infection has been well studied. It is essentially an invasive process, with the chromosomally encoded Stx playing an exacerbating rather than an initiating role, as alluded to above in the context of HC caused by EPEC. The pioneering, detailed genetic study of Shigella invasion, which became the paradigm for the study of several bacterial invasive systems (71), revealed the existence of a $220 \mathrm{~kb}$ virulence plasmid (72). This large plasmid encodes a type III system that secretes the products of plasmid Ipa (invasion plasmid antigen) genes encoding IpaA, B, C and D and IcsA; IpaB and C are the major effectors of entry into eukaryotic cells, and IcsA (intra-, intercellular spread) is the principal mediator of intercellular spread between epithelial cells. Recently, strides have been made in elucidating the biological correlates of this complex process $(73,74)$, a brief summary of which follows. Initial entry of $S$ dysenteriae into the colonic mucosa is via $\mathrm{M}$ cells in FAE, through which they migrate without killing the M cell. Shigellae species are then able to infect intestinal epithelial cells via their basolateral membranes; they do not penetrate via brush borders. Infected epithelial cells are induced to release the inflammatory cytokines interleukin (IL)-8 and tumour necrosis factor-alpha. In addition, Shigella species infect macrophages inducing IpaB-mediated apoptosis and IpaB-mediated release from those macrophages of IL-1 $\beta$, another potent inflammatory cytokine. The inflammatory response destabilizes epithelial integrity and permeability by the extrusion of PMN, thereby allowing direct access of more Shigella species to the basolateral membranes of epithelial cells. Interaction with PMN results in killing of organisms, with concomitant release of tissuedamaging granules. Once inside epithelial cells, IcsA-mediated intercellular spread of Shigella organisms takes place with consequent enlargement of the initial focus of infection.

Yersinia species: Yersinia pestis is transmitted from rats to humans by a flea bite, but Yersinia pseudotuberculosis and 


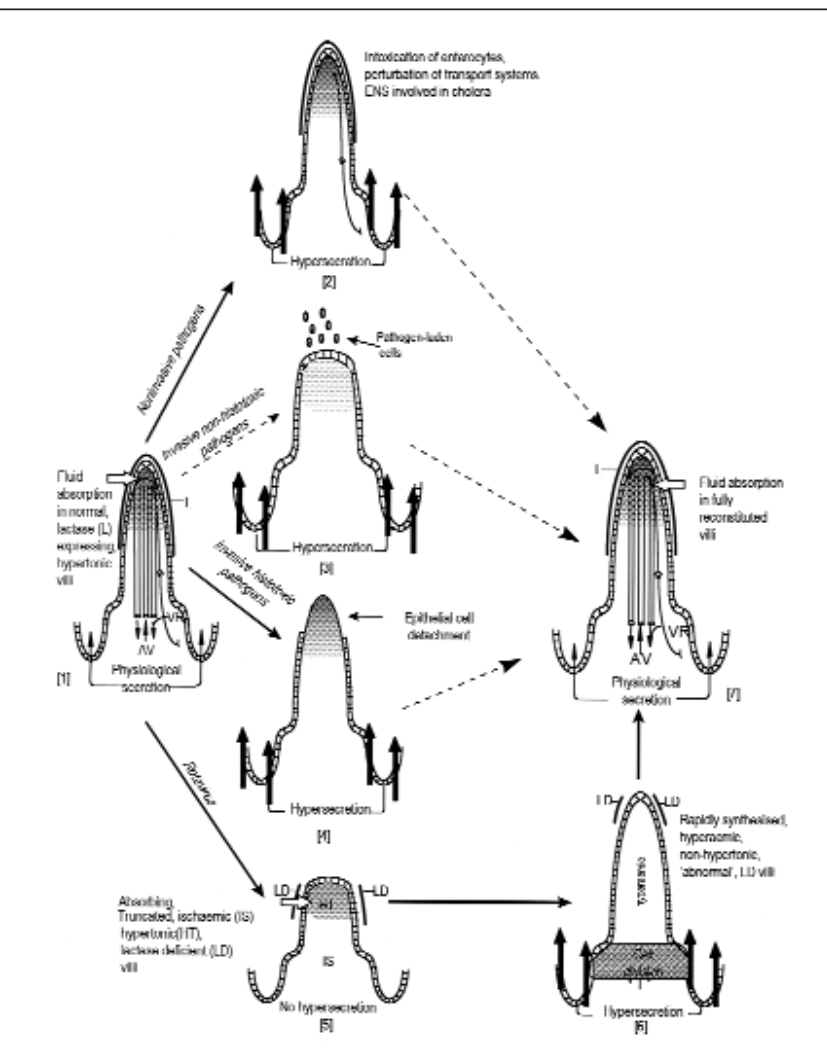

Figure 9) Diarrheal mechanisms: initial stages and (for rotavirus) some intermediate stages in disease progression. A schematic summary of diarrheal mechanisms in some of the infections discussed in the text. In all cases, broken arrows indicate uncertainty about the number and nature of intermediate steps in the return to normality of affected villi in self-limiting diarrheal disease. For clarity, the blood supply in [2] and both blood supply and enteric nervous system in [3], [4], [5] and [6] have been omitted. [1] A normal villus; the shading intensity (as in Figure 1) represents the magnitude of osmolarity. [2] Intoxication of villi by noninvasive pathogens such as Vibrio cholerae and enterotoxigenic Escherichia coli (ETEC). The main diarrheal determinant is cholera toxin (CT) in V cholerae and heat-labile toxins and heat-stable toxins in ETEC. However, as discussed in the text, toxins are not the whole story, hence the broken arrows. [3] Disease caused by invasive pathogens such as nonhistotoxic Salmonella typhimurium and rotavirus. Villi are shortened, with presumed loss of absorption and observed increase in secretion. Again, the mechanistic pathway for return to normality is not known. [4] Loss of epithelia due to a histotoxin seen in some strains of $S$ typhimurium. Loss of enterocytes affect absorption and open up other routes for progressive invasion. Note the broken arrow. [5] A more complete experimentally based understanding of the pathophysiological mechanisms is possible in rotavirus infection of neonatal mice ([5], [6] and [7]). The main point is that conventional wisdom is not sustained: maximum diarrhea occurred during the resynthesis of truncated villi, and villus shortening was preceded or caused by ischemia. Prolongation of diarrhea coincided with nonhypertonic villi; diarrhea ceased on reconstitution of hypertonic villus tip regions. It is possible to infer that some of these intermediate steps take place in other gut infections. AV Arterial vessel; VR Venous return. Reproduced with permission from reference 99

Yersinia enterocolitica are foodborne pathogens. Y pseudotuberculosis gives rise to mesenteric adenitis and septicemia, and $Y$ enterocolitica causes a broad range of gastrointestinal syndromes. From an enteric point of view, $Y$ enterocolitica appears to cross the intestinal epithelium via $\mathrm{M}$ cells, destroying Peyer's patches in the process $(73,75)$. This ability is mediated by an outer membrane protein, invasin. However, it is important to point out that $Y$ enterocolitica is not, as has been generally assumed in the past, an intracellular pathogen - an assumption that rested mainly on the ability of Yersinia species to invade cultured cells.

Yersinia is in fact an extracellular, potent antiphagocytic pathogen, particularly when present in lymph nodes. Much less is known about the mechanisms responsible for gastroenteritic syndromes caused by Yersinia species than those involved in resisting phagocytosis; the latter is an extremely important virulence attribute for an organism that, if phagocytosed, is readily killed! Strictly, the antiphagocytic property of Yersinia species is something outside the scope of this review. Nevertheless, brief allusion is made to this aspect because a great deal is known about the molecular basis of the antiphagocytic capability of Yersinia species, due largely to the work of Cornelis and colleagues (76-79). It has been shown that the capacity to resist host defence mechanisms depends on the Yop virulon, which is a sophisticated system encoded by more than 50 genes on a $70 \mathrm{~kb}$ plasmid (pYV) in Y enterocolitica. Upon contact with host cell membrane, expression of a type III secretion occurs. Effector proteins are delivered to the target eukaryotic cell, which disrupt cytoskeletal dynamics, which in the case of a phagocyte would render it powerless; eventually the phagocyte dies.

Clostridium difficile: $\mathrm{C}$ difficile is established as the most common nosocomial enteric pathogen, causing pseudomembranous colitis, antibiotic-associated colitis and antibiotic-associated diarrhea. The most important defence against this opportunistic pathogen is the normal colonic microflora (80), although the microbial species responsible for $\mathrm{C}$ difficile and the mechanisms whereby their growth is suppressed are still not understood. Disruption of the normal ecosystem by antibiotics can result in colonization by $\mathrm{C}$ difficile, which, if of the right pathotype, causes diarrhea or, more seriously, pseudomembranous colitis. Production of proteolytic and hydrolytic enzymes and capsule, expression of fimbriae and flagella, chemotaxis and adhesion to gut receptors, may all play a part in the pathogenesis of $\mathrm{C}$ difficile-induced disease by facilitating colonization or by directly contributing to tissue damage. However, toxins A and $\mathrm{B}$ are thought to be the primary virulence determinants of this pathogen in the context of antibiotic-associated gastrointestinal disease (81). The molecular organization, and control of expression of toxins $\mathrm{A}$ and $\mathrm{B}$ are now being unravelled (82). Toxins $\mathrm{A}$ and $\mathrm{B}$ belong to a group of clostridial toxins designated as large (A $308 \mathrm{kDa}$; B $269 \mathrm{kDa}$ ) clostridial cytotoxins, which have homologous protein sequences, and modify small GTP-binding proteins of the Ras superfamily (83) by their $\mathrm{N}$-terminal glycosyltransferase activity (84). This results in disruption and reorganization of cytoskeletal actin and cell rounding.

How do these toxins act in vivo, and can we interpret the disease process in terms of their activities? Both toxins 
are cytotoxic in vitro. B is approximately 1000 -fold more cytotoxic to cultured cells than A, yet a substantial body of evidence shows that $A$ is vastly more toxic to rabbit intestine than $\mathrm{B}$, which has little effect on animal mucosae in vivo on its own (85-87). The effect of $A$ on the rabbit terminal ileum was drastic, with near total destruction of villi and production of bloody proteinaceous fluid. In the colon, epithelia became detached, and hemorrhage was tissue localized: fluid was watery and nonproteinaceous $(85,86)$. In immunized animals, tissue hemorrhage was prevented but epithelial desquamation or fluid secretion in the rabbit colon was not (88). In experimental infection of hamsters, virulence of $\mathrm{C}$ difficile strains correlated with the degree of production in vivo of $A$ rather than $B$ (89). Later studies with human biopsies showed that toxin A binds directly to human colonocytes (90), causing them to detach, and induces production of the inflammatory cytokine IL-8 (91). Toxin A also killed lamina propria macrophages and $\mathrm{T}$ cells (92), which, these authors suggested, could be the basis of $\mathrm{C}$ difficile-induced suppression of immune responses. Thus, a powerful case can be marshalled to implicate toxin $\mathrm{A}$ as the major effector in $\mathrm{C}$ difficile diarrheal disease and of the colitis that is characteristic of $\mathrm{C}$ difficile infections.

However, as in all overly neat syntheses, there are awkward, ill-fitting pieces. Others (93) claim that in an in vitro Ussing chamber study, the human colon was 10 times more sensitive to toxin $\mathrm{B}$ than to toxin $\mathrm{A}$. A cytotoxigenic strain of $\mathrm{C}$ difficile has been described (94) that does not produce toxin $\mathrm{A}$, but causes classic hemorrhage and bloody fluid accumulation in rabbit ileal loops, and diarrhea in hamsters. Perhaps the biggest unsolved puzzle is that both these toxins have exactly the same enzymatic activity that results in the glycosylation of the same serine residue in target proteins, but yet they have very different biological properties. Attempts to explain this discrepancy have been made as follows (95). In cell culture systems, cytotoxicity correlated with the efficiency of toxin binding to cells. Moreover, although the specific glucosyltransferase activity of A was 100 times less than that of B, toxin A did modify an additional substrate. While it is difficult to see how this explains the dramatic effect(s) of toxin A on intact mucosae, it does point to the possibility that the primary biological effects are unrelated to glucosyltransferase enzyme activity but are due to some other mechanism. Branka et al (96) purport to demonstrate that the main effect of toxin $A$ is to upregulate the secretion of IL-8 from colonocytes (also suggested in 91) and downregulate the exocytosis of mucin. This would result in the recruitment of inflammatory and immune cells, with consequential indirect mucosal damage. The depression of mucin secretion could well be explained as a secondary effect in terms of the enzymatic activity of the toxin, which by disruption of the cytoskeleton would impair exocytosis. It would not be surprising to find that the explanation of differential histotoxicity lies in the C-terminal repeat sequences (which carry cell recognition and signal transducing?) sites in the larger A protein or, that these proteins are differentially multifunctional.

\section{CONCLUSIONS}

In this overview, a range of organisms have been considered, and examples of how the normal function of the gut is perturbed were provided. The emphasis has been on the microbial determinants and mechanisms involved in the primary interaction of pathogen with gut epithelia (Figure 9). Allusions have been made to subsequent involvement of host responses such as the inflammatory response, the production and release of potent cytokines, and accelerated homeostatic responses (as for example in rapid villus resynthesis) seen in many infections. While these host responses are clearly of great importance in the full explanation of diarrheal secretion, no attempts have been made to discuss them in detail, for two reasons: lack of space and lack of research-based competence of the reviewer.

\section{ADDENDUM}

Attention is drawn to two papers. Blocker et al (97) present beautiful electron microscopic visualization of the Shigella needle complex, which forms an essential part of the type III secretion system ('secreton'), which delivers to target cells those effector proteins that initiate the process leading to bacillary dysentery. Comparisons and contrasts are drawn with equivalent systems in Salmonella and E coli. In a study by Roby et al (98), a chromosomal locus was cloned which mapped at $c$ centisome 25 on the Salmonella chromosome close to, but distinct from, SPI-5. The biological properties of the recombinant clone suggest that it encodes a 'gutresponsive' pleiotropic regulator of genes involved in adaptation to the in vivo gut environment and gastroenteritic virulence.

ACKNOWLEDGEMENTS: It is a duty and pleasure to acknowledge my $\mathrm{PhD}$ students, postdoctoral research fellows and staff colleagues, past and present, for their intellectual and practical contributions to the work of our laboratory cited here and for constructive criticism of the manuscript, and The Wellcome Trust for generous grant financial support over many years. We also thank Dr Stuart Knutton for Figures 5 and 6 - the latter being an updated version of that from reference 20 .

\section{REFERENCES}

1. Jodal M, Hallback DA, Lundgren O. Tissue osmolality in intestinal villi during luminal perfusion with isotonic electrolyte solutions. Acta Physiol Scand Suppl 1978;107:94-107.

2. Osborne MP, Haddon SJ, Worton KJ, et al. A study of the microcirculation in whole villi of neonatal mice using a peroxidase histochemical staining method. J Pediatr Gastroenterol Nutr 1991;12:105-10.

3. Osborne MP, Haddon SJ, Worton KJ, et al. Rotavirus-induced changes in the microcirculation of intestinal villi of neonatal mice in relation to the induction and persistence of diarrhea. J Pediatr Gastroenterol Nutr 1991;12:111-20.

4. Brown DR, O'Grady SM. Regulation of ion transport in the porcine intestinal tract by enteric neurotransmitters and hormones. Comp Biochem Physiol A 1997;118:309-17.

5. Collins J, Candy DCA, Starkey WG, Spencer AJ, Osborne MP, Stephen J. Disaccharidase activities in small-intestine of rotavirusinfected suckling mice - a histochemical study. J Pediatr Gastroenterol Nutr 1990;11:395-403.

6. Karaolis DKR, Somara S, Maneval DR, Johnson JA, Kaper JB. A bacteriophage encoding a pathogenicity island, a type-IV pilus and a phage receptor in cholera bacteria. Nature 1999;399:375-9. 
7. Kaper JB, Morris JG, Levine MM. Cholera. Clin Microbiol Rev 1995;8:48-86.

8. Herrington DA, Hall RH, Losonsky G, Mekalanos JJ, Taylor RK, Levine MM. Toxin, toxin-coregulated pili, and the toxr regulon are essential for Vibrio cholerae pathogenesis in humans. J Exp Med 1988;168:1487-92.

9. Lencer WI, Hirst TR, Holmes RK. Membrane traffic and the cellular uptake of cholera toxin. Biochim Biophys Acta Mol Cell Res 1999;1450:177-90.

10. Fasano A, Baudry B, Pumplin DW, et al. Vibrio cholerae produces a 2nd enterotoxin, which affects intestinal tight junctions. Proc Natl Acad Sci USA 1991;88:5242-6.

11. Baudry B, Fasano A, Ketley J, Kaper JB. Cloning of a gene (zot) encoding a new toxin produced by Vibrio cholerae. Infect Immun 1992;60:428-34.

12. Mathan MM, Chandy G, Mathan VI. Ultrastructural changes in the upper small intestinal mucosa in patients with cholera. Gastroenterology 1995;109:422-30.

13. Silva TMJ, Schleupner MA, Tacket CO, et al. New evidence for an inflammatory component in diarrhea caused by selected new, live attenuated cholera vaccines and by El Tor and O139 Vibrio cholerae. Infect Immun 1996;64:2362-4

14. Lundgren $\mathrm{O}$, Jodal $\mathrm{M}$. The enteric nervous system and cholera toxin-induced secretion. Comp Biochem Physiol A 1997;118:319-27.

15. Nocerino A, Iafusco M, Guandalini S. Cholera toxin-induced smallintestinal secretion has a secretory effect on the colon of the rat. Gastroenterology 1995;108:34-9.

16. Nataro JP, Kaper JB. Diarrheagenic Escherichia coli. Clin Microbiol Rev 1998;11:142-201.

17. Pérès SY, Marchès $O$, Daigle $F$, et al. A new cytolethal distending toxin (CDT) from Escherichia coli producing CNF2 blocks HeLa cell division in G2/M phase. Mol Microbiol 1999;24:1095-107.

18. Gaastra W, Svennerholm AM. Colonization factors of human enterotoxigenic Escherichia coli (ETEC). Trends Microbiol 1996;4:444-52.

19. Carpick BW, Gariepy J. The Escherichia coli heat-stable enterotoxin is a long-lived superagonist of guanylin. Infect Immun 1993;61:4710-15.

20. Frankel G, Phillips AD, Rosenshine I, Dougan G, Kaper JB, Knutton S. Enteropathogenic and enterohaemorrhagic Escherichia coli: more subversive elements. Mol Microbiol 1998;30:911-21.

21. Hartland EL, Batchelor M, Delahay RM, et al. Binding of intimin from enteropathogenic Escherichia coli to Tir and to host cells. Mol Microbiol 1999;32:151-8.

22. Fagundes Neto U, Freymuller E, Gatti MS, Schmitz LG, Scaletsky I. Enteropathogenic Escherichia coli O111ab: H2 penetrates the smallbowel epithelium in an infant with acute diarrhea. Acta Paediatrica 1995;84:453-5.

23. Henderson IR, Navarro-Garcia F, Nataro JP. The great escape: structure and function of the autotransporter proteins. Trends Microbiol 1998;6:370-8.

24. Liu H, Magoun L, Luperchio S, Schauer DB, Leong JM. The Tirbinding region of enterohaemorrhagic Escherichia coli intimin is sufficient to trigger actin condensation after bacterial-induced bost cell signalling. Mol Microbiol 1999;34:67-81.

25. Donnenberg MS, Tacket CO, James SP, et al. Role of the eaeA gene in experimental enteropathogenic Escherichia coli infection. J Clin Invest 1993;92:1412-7.

26. Kelly G, Prasannan S, Daniell S, et al. Structure of the cell-adhesion fragment of intimin from enteropathogenic Escherichia coli. Nature Structural Biol 1999;6:313-8.

27. Sjogren R, Neill R, Rachmilewitz D, et al. Role of Shiga-like toxin-1 in bacterial enteritis - comparison between isogenic Escherichia coli strains induced in rabbits. Gastroenterology 1994;106:306-17.

28. Fontaine A, Arondel J, Sansonetti PJ. Role of Shiga toxin in the pathogenesis of bacillary dysentery, studied by using a Tox- mutant of Shigella dysenteriae-1. Infect Immun 1988;56:3099-109.

29. Uchida H, Kiyokawa N, Horie H, Fujimoto J, Takeda T. The detection of Shiga toxins in the kidney of a patient with hemolytic uremic syndrome. Pediatr Res 1999;45:133-7.

30. Wallis TS, Starkey WG, Stephen J, Haddon SJ, Osborne MP, Candy DCA. The nature and role of mucosal damage in relation to Salmonella typhimurium-induced fluid secretion in the rabbit ileum. J Med Microbiol 1986;22:39-49.

31. Amin II, Douce GR, Osborne MP, Stephen J. Quantitative studies of invasion of rabbit ileal mucosa by Salmonella typhimurium strain which differ in virulence in a model of gastroenteritis. Infect Immun 1994;62:569-78.

32. Lodge J, Douce GR, Amin II, et al. Biological and geneticcharacterization of TnphoA mutants of Salmonella typhimurium TML in the context of gastroenteritis. Infect Immun 1995;63:762-9.

33. Bolton AJ, Martin GD, Osborne MP, Wallis TS, Stephen J. Invasiveness of Salmonella serotypes Typhimurium, Choleraesuis and Dublin for rabbit terminal ileum in vitro. J Med Microbiol 1999:48:800-810.

34. Bolton AJ, Osborne MP, Wallis TS, Stephen J. Interaction of Salmonella choleraesuis, Salmonella dublin and Salmonella typhimurium with porcine and bovine terminal ileum in vivo. Microbiology 1999;145:2431-41.

35. Lodge JM, Bolton AJ, Martin GD, Osborne MP, Ketley JM, Stephen J. A histotoxin produced by Salmonella. J Med Microbiol 1999;48:811-18

36. Jones BD, Ghori N, Falkow S. Salmonella typhimurium initiates murine infection by penetrating and destroying the specialized epithelial M cells of the Peyer's-patches. J Exp Med 1994;180:15-23.

37. Watson PR, Paulin SM, Bland AP, Jones PW, Wallis TS. Characterization of intestinal invasion by Salmonella typhimurium and Salmonella dublin and effect of a mutation in the inv $\mathrm{H}$ gene. Infect Immun 1995;63:2743-54.

38. Frost AJ, Bland AP, Wallis TS. The early dynamic response of the calf ileal epithelium to Salmonella typhimurium. Vet Pathol 1997:34:369-86.

39. Wallis TS, Starkey WG, Stephen J, Haddon SJ, Osborne MP, Candy DCA. Enterotoxin production by Salmonella typhimurium strains of different virulence. J Med Microbiol 1986;21:19-23.

40. Stephen J, Wallis TS, Starkey WG, Candy DCA, Osborne MP, Haddon S. Salmonellosis - in retrospect and prospect. Ciba Found Symp 1985;112:175-92.

41. Bolton AJ, Osborne MP, Stephen J. Comparative study of the invasiveness of Salmonella serotypes Typhimurium, Choleraesuis and Dublin for Caco-2 cells, HEp-2 cells and rabbit ileal epithelia. J Med Microbiol 2000;49:503-11.

42. Watson PR, Galyov EE, Paulin SM, Jones PW, Wallis TS. Mutation of inv $\mathrm{H}$, but not stn, reduces Salmonella-induced enteritis in cattle. Infect Immun 1998;66:1432-8.

43. Wallis TS, Hawker RJH, Candy DCA, et al. Quantification of the leucocyte influx into rabbit ileal loops induced by strains of Salmonella typhimurium of different virulence. J Med Microbiol 1989;30:149-56

44. Wallis TS, Vaughan ATM, Clarke GJ, et al. The role of leukocytes in the induction of fluid secretion by Salmonella typhimurium. J Med Microbiol 1990;31:27-35.

45. Wallis TS, Galyov EE. MicroReview. Molecular basis of Salmonellainduced enteritis. Mol Microbiol 2000;36:997-1005.

46. Groisman EA, Blanc-Potard A-B, Keiichi U. Pathogenicity islands and the evolution of Salmonella virulence. In: Kaper JB,

Hacker J, eds. Pathogenicity Islands and Other Mobile Genetic Elements. Washington: American Society for Microbiology, 1999:127-50

47. Wood MW, Jones MA, Watson PR, Hedges S, Wallis TS, Galyov EE. Identification of a pathogenicity island required for Salmonella enteropathogenicity. Mol Microbiol 1998;29:883-91.

48. Collazo CM, Galan JE. Requirement for exported proteins in secretion through the invasion-associated Type-III system of Salmonella typhimurium. Infect Immun 1996;64:3524-31.

49. Galyov EE, Wood MW, Rosqvist R, et al. A secreted effector protein of Salmonella dublin is translocated into eukaryotic cells and mediates inflammation and fluid secretion in infected ileal mucosa. Mol Microbiol 1997;25:903-12.

50. Fu YX, Galan JE. The Salmonella typhimurium tyrosine phosphatase SptP is translocated into host cells and disrupts the actin cytoskeleton. Mol Microbiol 1998;27:359-68.

51. Darwin KH, Miller VL. Molecular basis of the interaction of Salmonella with the intestinal mucosa. Clin Microbiol Rev 1999;12:405-28.

52. Worton KJ, Candy DCA, Wallis TS, et al. Studies on early association of Salmonella typhimurium with intestinal mucosa in vivo and in vitro - relationship to virulence. J Med Microbiol 1989;29:283-94

53. Ginocchio CC, Olmsted SB, Wells CL, Galan JE. Contact with epithelial-cells induces the formation of surface appendages on Salmonella typhimurium. Cell 1994;76:717-24.

54. Starkey WG, Collins J, Wallis TS, et al. Kinetics, tissue-specificity 
and pathological changes in murine rotavirus infection of mice. J Gen Virol 1986;67:2625-34.

55. Osborne MP, Haddon SJ, Spencer AJ, et al. An electron-microscopic investigation of time-related changes in the intestine of neonatal mice infected with murine rotavirus. J Pediatr Gastroenterol Nutr 1988;7:236-48.

56. Collins J, Starkey WG, Wallis TS, et al. Intestinal enzyme profiles in normal and rotavirus-infected mice. J Pediatr Gastroenterol Nutr 1988;7:264-72.

57. Stephen J, Osborne MP. Pathophysiological mechanisms in diarrhoeal disease. In: Donachie W, Griffiths E, Stephen J, eds. Bacterial Infections of Respiratory and Gastrointestinal Mucosae. Special Publications of the Society for General Microbiology, vol 24, 1988.

58. Starkey WG, Candy DCA, Thornber D, et al. An in vitro model to study aspects of the pathophysiology of murine rotavirus-induced diarrhea. J Pediatr Gastroenterol Nutr 1990;10:361-70.

59. Starkey WG, Collins J, Candy DCA, Spencer AJ, Osborne MP, Stephen J. Transport of water and electrolytes by rotavirus-infected mouse intestine - a time course study. J Pediatr Gastroenterol Nutr 1990;11:254-60.

60. Spencer AJ, Osborne MP, Haddon SJ, et al. X-ray-microanalysis of rotavirus-infected mouse intestine - a new concept of diarrheal secretion. J Pediatr Gastroenterol Nutr 1990;10:516-29.

61. Robinson JWL, Mirkovitch V, Winstorfer B, Saegesser F. Response of the intestinal mucosa to ischaemia. Gut 1981;22:512-27.

62. Warley A, Stephen J, Hockaday A, Appleton TC. X-raymicroanalysis of HeLa S3 cells. 2. Analysis of elemental levels during the cell-cycle. J Cell Sci 1983;62:339-50.

63. Charney AN, Feldman G. Systematic acid base disorders and intestinal electrolyte transport. Am J Physiol 1984;247:G1-2.

64. Ketley JM. Pathogenesis of enteric infection by Campylobacter. Microbiology 1997;143:5-21.

65. Wooldridge KG, Ketley JM. Campylobacter host cell interactions. Trends Microbiol 1997;5:96-102.

66. Yuki N. Pathogenesis of Guillain-Barre and Miller Fisher Syndromes subsequent to Campylobacter jejuni enteritis. Jpn J Infect Dis 1999;52:99-105.

67. Wooldridge KG, Williams PH, Ketley JM. Host signal transduction and endocytosis of Campylobacter jejuni. Microbiol Pathog 1996;21:299-305

68. Konkel ME, Kim BJ, Rivera-Amill V, Garvis SG. Bacterial secreted proteins are required for the internalization of Campylobacter jejuni into cultured mammalian cells. Mol Microbiol 1999;32:691-701.

69. Pallen M, Wren B, Parkhill J. 'Going wrong with confidence': misleading sequence analyses of Ciab and ClpX. Mol Microbiol 1999;34:195.

70. Wren B. Chips with everything. Microarrays and medicine. Wellcome News: From Genome to Health 1999;Q3:16-7.

71. Sansonetti PJ. Molecular and cellular mechanisms of invasion of the intestinal barrier by enteric pathogens. The paradigm of Shigella. Folia Microbiol 1998;43:239-46.

72. Maurelli AT, Baudry B, d'Hauteville H, Hale TL, Sansonetti PJ. Cloning of plasmid DNA sequences involved in invasion of HeLa cells by Shigella flexneri. Infect Immun 1985;49:164-71.

73. Sansonetti PJ, Phalipon A. M cells as ports of entry for enteroinvasive pathogens: Mechanisms of interaction, consequences for the disease process. Semin Immunol 1999;11:193-203.

74. Sansonetti PJ, Arondel J, Huerre M, Harada A, Matsushima K. Interleukin-8 controls bacterial transepithelial translocation at the cost of epithelial destruction in experimental shigellosis. Infect Immun 1999;67:1471-80.

75. Hartland EL, Robins-Browne RM. Infections with enteropathogenic Yersinia species: paradigms of bacterial pathogenesis. Rev Med Microbiol 1998;9:191-205.

76. Cornelis GR, Wolf-Watz H. The Yersinia Yop virulon: A bacterial system for subverting eukaryotic cells. Mol Microbiol 1997;23:861-7.

77. Cornelis GR. Cross-talk between Yersinia and eukaryotic cells. In: McCrae MA, Saunders JR, Smyth CJ, Stow ND, eds. Molecular Aspects of Host-Pathogen Interactions. Cambridge: Cambridge University Press 1997:45-65.
78. Iriarte M, Cornelis GR. Identification of SycN, YscX, and $\mathrm{Ysc} Y$, three new elements of the Yersinia Yop virulon. J Bacteriol 1999;181:675-80.

79. Neyt C, Cornelis GR. Role of SycD, the chaperone of the Yersinia Yop translocators YopB and YopD. Mol Microbiol 1999;31:143-56.

80. Wilson KH. The microecology of Clostridium difficile. Clin Infect Dis 1993;16:S214-8

81. Borriello SP. Pathogenesis of Clostridium difficile infection. J Antimicrob Chemother 1998;41:13-9.

82. Dupuy B, Sonenshein AL. Regulated transcription of Clostridium difficile toxin genes. Mol Microbiol 1998;27:107-20.

83. Eichel Streiber Cv, Boquet P, Sauerborn M, Thelestam M. Large Clostridial cytotoxins - A family of glycosyltransferases modifying small GTP-binding proteins. Trends Microbiol 1996;4:375-82.

84. Faust C, Ye B, Song KP. The enzymatic domain of Clostridium difficile toxin $\mathrm{A}$ is located within its $\mathrm{N}$-terminal region. Biochem Biophys Res Com 1998;251:100-5.

85. Mitchell TJ, Ketley JM, Haslam SC, et al. Effect of toxin A and toxin B of Clostridium difficile on rabbit ileum and colon. Gut 1986;27:78-85.

86. Mitchell TJ, Ketley JM, Burdon DW, Candy DCA, Stephen J. Biological mode of action of Clostridium difficile toxin A - a novel enterotoxin. J Med Microbiol 1987;23:211-9.

87. Lima AAM, Lyerly DM, Wilkins TD, Innes DJ, Guerrant RL. Effects of Clostridium difficile toxin A and toxin B in rabbit small and largeintestine in vivo and on cultured cells in vitro. Infect Immun 1988;56:582-8.

88. Ketley JM, Mitchell TJ, Candy DCA, Burdon DW, Stephen J. The effects of Clostridium difficile crude toxins and toxin A on ileal and colonic loops in immune and non-immune rabbits. J Med Microbiol 1987;24:41-52.

89. Borriello SP, Ketley JM, Mitchell TJ, et al. Clostridium difficile a spectrum of virulence and analysis of putative virulence determinants in the hamster model of antibiotic-associated colitis. J Med Microbiol 1987;24:53-64.

90. Smith JA, Cooke DL, Hyde S, Borriello SP, Long RG. Clostridium difficile toxin A binding to human intestinal epithelial cells. J Med Microbiol 1997:46:953-8.

91. Mahida YR, Makh S, Hyde S, Gray T, Borriello SP. Effect of Clostridium difficile toxin A on human intestinal epithelial cells: induction of interleukin 8 production and apoptosis after cell detachment. Gut 1996;38:337-47.

92. Mahida YR, Galvin A, Makh S, et al. Effect of Clostridium difficile toxin A on human colonic lamina propria cells: Early loss of macrophages followed by T-cell apoptosis. Infect Immun 1998;66:5462-9.

93. Riegler M, Sedivy R, Pothoulakis C, et al. Clostridium difficile toxin B is more potent than toxin $\mathrm{A}$ in damaging human colonic epithelium in vitro. J Clin Invest 1995;95:2004-11.

94. Borriello SP, Wren BW, Hyde S, et al. Molecular, immunological, and biological characterization of a toxin A-negative, toxin B-positive strain of Clostridium difficile. Infect Immun 1992;60:4192-9.

95. Chaves-Olarte E, Weidmann M, Eichel-Streiber CV, Thelestam M. Toxins A and B from Clostridium difficile differ with respect to enzymatic potencies, cellular substrate specificities, and surface binding to cultured cells. J Clin Invest 1997;100:1734-41.

96. Branka JE, Vallette G, Jarry A, et al. Early functional effects of Clostridium difficile toxin A on human colonocytes. Gastroenterology 1997;112:1887-94

97. Blocker A, Jouihri N, Larquet E, et al. Structure and composition of the Shigella flexneri 'needle complex', a part of its type III secreton. Mol Microbiol 2001;39:652-63.

98. Robey M, Morgan E, Lodge JM, et al. A new chromosomal locus associated with gut-modulated phenotypes in Salmonella serotype Typhimurium. J Med Microbiol. (In the press)

99. Mims CA, Nash A, Stephen J, eds. Mims' Pathogenesis of Infectious Disease, 5th edn. London: Academic Press, Harcourt Brace and Co, 2000.

100. Knutton S, Lloyd DR, McNeish AS. Adhesion of enteropathogenic Escherichia coli to human intestinal enterocytes and cultured human intestinal mucosa. Infect Immun 1987;55:69-77. 


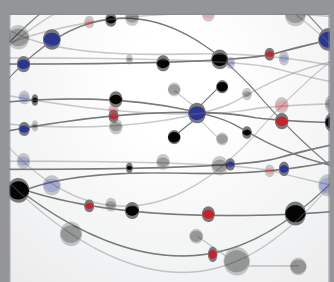

The Scientific World Journal
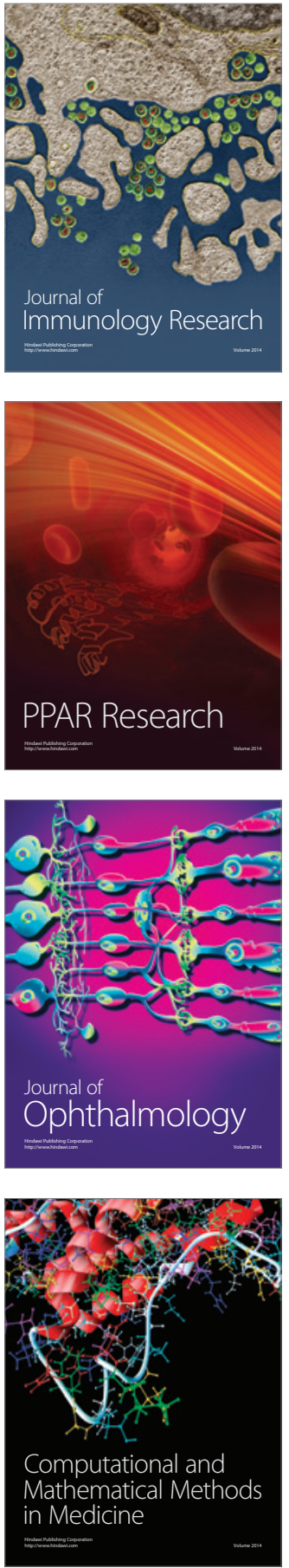

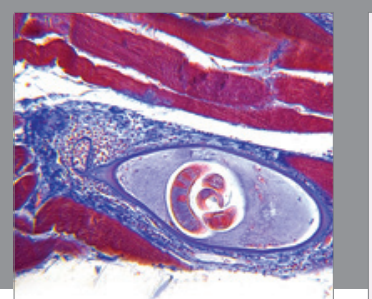

Gastroenterology Research and Practice

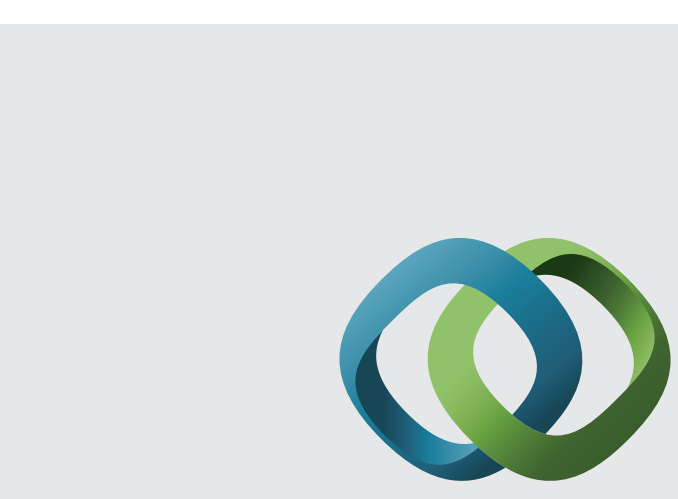

\section{Hindawi}

Submit your manuscripts at

http://www.hindawi.com
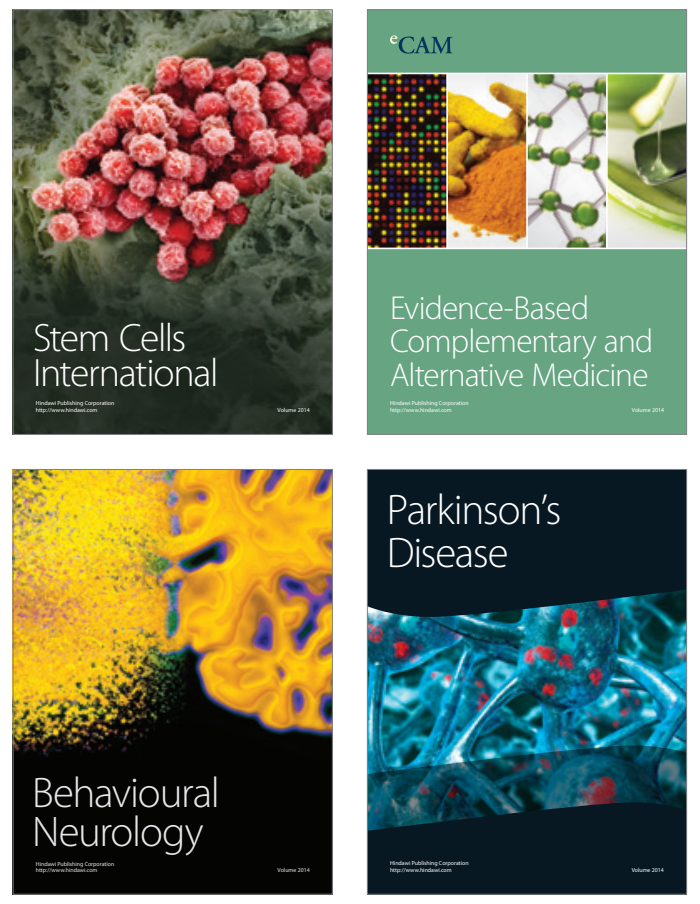
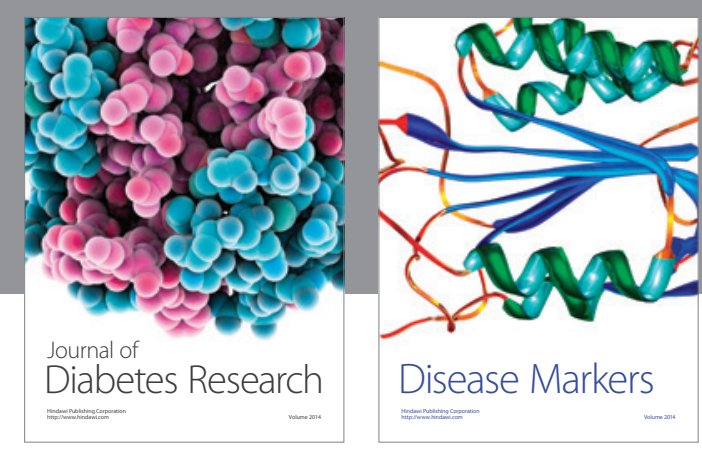

Disease Markers
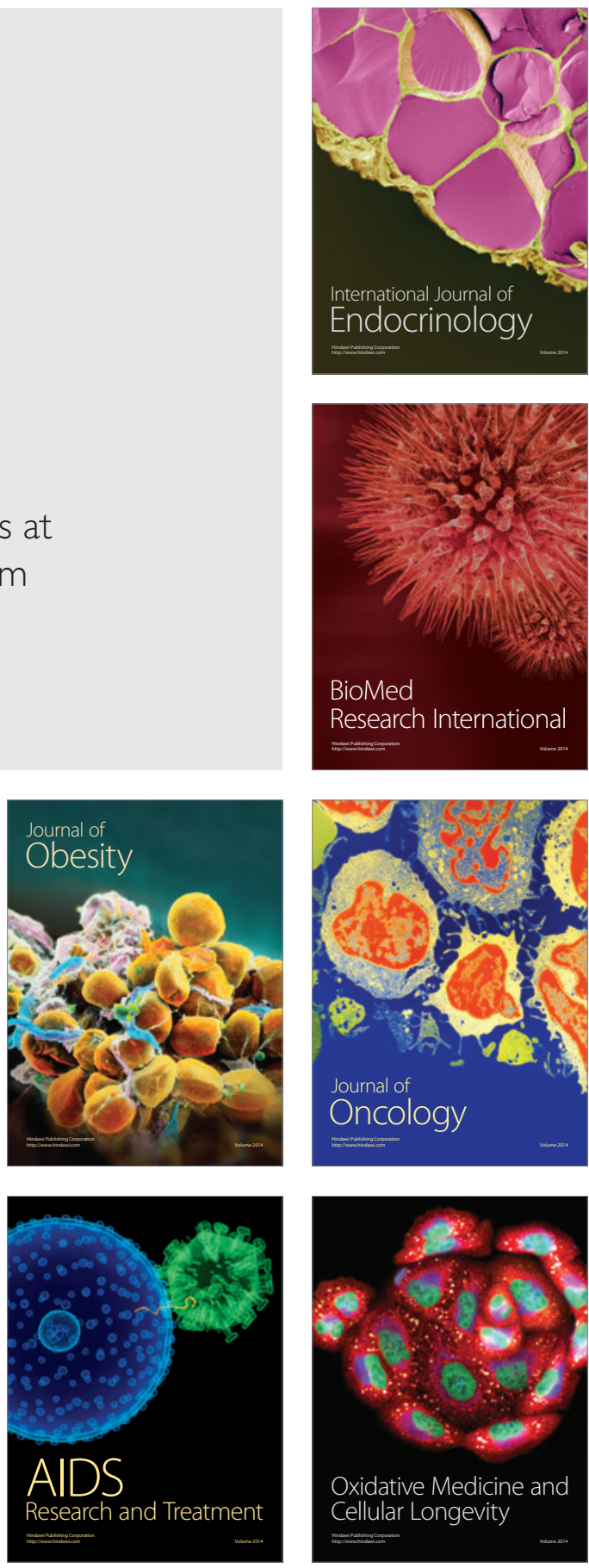